\title{
Barcoding lichen-forming fungi using 454 pyrosequencing is challenged by artifactual and biological sequence variation ${ }^{1}$
}

\author{
Kristiina Mark, Carolina Cornejo, Christine Keller, Daniela Flück, and Christoph Scheidegger
}

\begin{abstract}
Although lichens (lichen-forming fungi) play an important role in the ecological integrity of many vulnerable landscapes, only a minority of lichen-forming fungi have been barcoded out of the currently accepted $\sim 18000$ species. Regular Sanger sequencing can be problematic when analyzing lichens since saprophytic, endophytic, and parasitic fungi live intimately admixed, resulting in low-quality sequencing reads. Here, high-throughput, long-read 454 pyrosequencing in a GS FLX+System was tested to barcode the fungal partner of 100 epiphytic lichen species from Switzerland using fungal-specific primers when amplifying the full internal transcribed spacer region (ITS). The present study shows the potential of DNA barcoding using pyrosequencing, in that the expected lichen fungus was successfully sequenced for all samples except one. Alignment solutions such as BLAST were found to be largely adequate for the generated long reads. In addition, the NCBI nucleotide database-currently the most complete database for lichenforming fungi-can be used as a reference database when identifying common species, since the majority of analyzed lichens were identified correctly to the species or at least to the genus level. However, several issues were encountered, including a high sequencing error rate, multiple ITS versions in a genome (incomplete concerted evolution), and in some samples the presence of mixed lichen-forming fungi (possible lichen chimeras).
\end{abstract}

Key words: 454 pyrosequencing, DNA barcoding, intragenomic variation, internal transcribed spacer, lichenized fungi.

Résumé : Bien que les lichens (champignons lichénisés) jouent un rôle important dans l'intégrité écologique du plusieurs environnements vulnérables, seule une minorité de champignons lichénisés ont été examinés au moyen de codes à barres sur un total de $\sim 18000$ espèces reconnues. Le séquençage Sanger standard peut s'avérer problématique lorsqu'on analyse les lichens en raison de la présence de champignons saprophytes, endophytes et parasitiques qui y sont intimement associés, ce qui produit des lectures de faible qualité. Dans ce travail, un pyroséquençage 454 à haut débit produisant de longues séquences sur un système GS FLX+a été testé pour réaliser un codage à barres de la composante fongique de 100 espèces de lichens épiphytes provenant de la Suisse. Des amorces spécifiques des champignons ont été employées pour amplifier l'espaceur interne transcrit (ITS) au complet. Ce travail montre le potentiel des codes à barres réalisés au moyen du pyroséquençage, car les champignons lichénisés attendus ont été séquencés avec succès pour tous les échantillons sauf un. Les outils d'alignement comme BLAST se sont avérés largement adéquats pour l'analyse des longues séquences. De plus, la base de données NCBI - de loin la plus complète pour les champignons lichénisés - peut servir de base de référence pour l'identification des espèces communes, puisque la majorité des lichens analysés ont été correctement identifiés à l'espèce ou à tout le moins au genre. Cependant, plusieurs problèmes ont été rencontrés, incluant un taux d'erreurs élevé, de multiples versions de l'ITS au sein d'un génome (évolution concertée incomplète), et la présence dans certains échantillons de plus d'un champignon lichénisé (possiblement dû à des lichens chimériques). [Traduit par la Rédaction]

Mots-clés : pyroséquençage 454, codage à barres de l'ADN, variation intragénomique, espaceur interne transcrit, champignons lichénisés.

Received 30 November 2015. Accepted 10 May 2016.

Corresponding Editor: Jianping Xu.

K. Mark.* Biodiversity and Conservation Biology, Swiss Federal Research Institute WSL, Switzerland; Institute of Botany and Ecology, University of Tartu, Estonia.

C. Cornejo, C. Keller, D. Flück, and C. Scheidegger. Biodiversity and Conservation Biology, Swiss Federal Research Institute WSL, Switzerland.

Corresponding author: Kristiina Mark (email: kristiina.mark@ut.ee).

*Awarded the Genome Prize for Research Excellence by a graduate student at the 6th International Barcode of Life Conference.

${ }^{1}$ This paper is part of a special issue entitled Barcodes to Biomes.

Copyright remains with the author(s) or their institution(s). This work is licensed under a Creative Commons Attribution 4.0 International License (CC BY 4.0), which permits unrestricted use, distribution, and reproduction in any medium, provided the original author(s) and source are credited. 


\section{Introduction}

Lichens are intimate and long-term symbiotic associations consisting of a heterotrophic fungal partner-also called the mycobiont-and photosynthetic algae or cyanobacteria-also called the photobiont (Nash 2008). In a systematic context, lichens are named after the fungal partner, and according to most recent estimates, about $18 \%$ of all fungal species are lichen-forming (Feuerer and Hawksworth 2007). While lichens include many bio-indicators for monitoring environmental qualityincluding air pollution and ecological integrity of forest landscapes (Nimis et al. 2002) - accurate identification of lichenized fungal species remains challenging (Lumbsch and Leavitt 2011). DNA-based specimen identification to a species level is useful in a system of well-circumscribed taxa and a high-quality reference database (Seifert 2009; Begerow et al. 2010). Recently, the internal transcribed spacer region (ITS) of the nuclear ribosomal RNA cistron was proposed as the primary fungal barcode marker (Schoch et al. 2012). However, only a minority of lichenforming fungi have been barcoded from the estimated 17500 species (Feuerer and Hawksworth 2007). For example, the largest and most typical order of lichen-forming fungi (Lecanorales) consists of about 5700 species, but only about $29 \%$ of them have publicly available ITS sequences in sequence databases such as the National Institute of Health's (NIH) genetic sequence database, GenBank (http://www.ncbi.nlm.nih.gov/genbank/; accessed 28 September 2015), the Barcode of Life Data System (BOLD; www.boldsystems.org; Ratnasingham and Hebert 2007), and UNITE (https://unite.ut.ee/; accessed 24 November 2015; Abarenkov et al. 2010).

Barcoding lichens using Sanger sequencing has been successful in some groups of lichens (Kelly et al. 2011; Divakar et al. 2016), especially with foliose and fruticose lichens; however, in crustose lichens - that constitute by far the vast majority of lichenized species (Bergamini et al. 2005)-it often proves quite challenging (Flück 2012). Sampling difficulties occur where other very similar lichen species live mixed or close by, and many saprophytic, endophytic, and parasitic fungi also live intimately admixed with the lichen mycobiont, making the application of Sanger sequencing insufficient in many cases (Flück 2012; Orock et al. 2012). A limited number of studies are known to have successfully applied pyrosequencing to recover the identity of a lichen, when Sanger sequencing failed to produce usable results (Hodkinson and Lendemer 2013; Lücking et al. 2014a).

Recent advancements in pyrosequencing methods now allow the amplification of fragments up to 1000 base pairs (bp) in the GS FLX+ system of Roche/454 pyrosequencing. However, 454 pyrosequencing is notorious for its high indel (short insertions and deletions) error rate in homopolymeric regions (three or more identical nucleotites) and carry-forward-incomplete-extension (CAFIE) errors (Margulies et al. 2005; Huse et al. 2007; Gilles et al. 2011; Lücking et al. 2014b). In addition to artifactual sequence variation, biological sequence variation-such as intragenomic and (or) intramycelial (i.e., allelic heterozygosity) variation of this multicopy gene-may be possible(Wörheide et al. 2004; Simon and Weiß 2008; Lindner et al. 2013).

The aim of our study was to test whether lichen mycobiont can be successfully identified to a single species using DNA barcoding through pyrosequencing the ITS marker of 100 species of both foliose-fruticose and crustose lichens, using fungal-specific markers in the highthroughput 454 sequencing in the GS FLX+ system, while elucidating and quantifying artifactual and biological sequence variation.

\section{Materials and methods}

Taxon sampling and morphology-based identification

One hundred lichen specimens, including 52 crustose species and 48 macrolichens (foliose and fruticose thalli), were collected from different locations in Switzerland in 2011 and 2014. The full list of specimens with voucher information is given in Table 1 . Additional specimen data-such as the collection GPS coordinates, substrate, specimen photographs, the primary ITS barcodes - are available though a public BOLD dataset DOI: dx.doi.org/10.5883/DS-LICODE. All project data can also be accessed though the PlutoF cloud database under project "Barcoding Swiss lichens using 454 pyrosequencing” (https://plutof.ut.ee/\#/study/view/ 31890). Specimen identifications of the collected material were based on morphological and chemical characters, following the nomenclature of Clerc and Truong (2012). Lichen chemistry was examined with standardized thin layer chromatography (TLC) using solvent systems A, B, and C (Culberson and Ammann 1979, White and James 1985). Sorediate Bacidia and Lecanora species without apothecia, samples \#6, \#7, and \#42, could not be identified to the species level and were left as Bacidina arnoldiana aggregate (aggr.) and Lecanora strobilina aggr., respectively. Specimen LC-088, determined as Lecidella sp., includes an undescribed chemotype for Lecidella (arthothelin, 2,4-dichloronorlichexanthone), and BC-47-1 Lecanora sp. morphologically resembles Haematomma ochroleucum or Biatora flavopunctata, with atranorin, usnic acid, and zeorin identified as secondary substances. Specimens with poorly expressed diagnostic characters were re-checked in light of barcoding data, and the determination of five specimens was corrected (LC-023 Lecanora cf. umbrina $\Rightarrow$ Lecania cf. cyrtella, BC-027-1 Haematomma aff. ochroleucum or Biatora flavopunctata $\Rightarrow$ Lecanora sp., BC-155-5 Lecidea nylanderi $\Rightarrow$ Loxospora elatina, BC-161-5 Lecanora farinaria/expersa $\Rightarrow$ Loxospora elatina, KM03-02 Usnea florida $\Rightarrow$ Usnea intermedia). All specimens are stored at the WSL Swiss Federal Research Institute at $-20^{\circ} \mathrm{C}$.

\section{Molecular methods}

About 3-5 mg of visually uncontaminated lichen thallus of each specimen was sampled for molecular analyses. In sampling, vegetative thallus was preferred, but in some apotheciate crustose species with no visible 


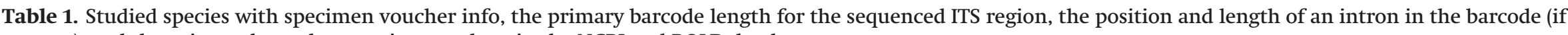
present), and the primary barcode accession numbers in the NCBI and BOLD databases.

\begin{tabular}{|c|c|c|c|c|c|c|}
\hline No. & Target taxon & Collection data (site, date, ID) & $\begin{array}{l}\text { Barcode } \\
\text { length (bp) }\end{array}$ & $\begin{array}{l}\text { Group I intron } \\
\text { length (bp) } \\
\text { and position }\end{array}$ & $\begin{array}{l}\text { GenBank } \\
\text { No. }\end{array}$ & BOLD No. \\
\hline 1 & Alectoria sarmentosa (Ach.) Ach. & CH-Bern; 06.02.2014; LC-064 & 579 & & KX132948 & LIFU039-16 \\
\hline 2 & Anaptychia crinalis (Schleich. ex Schaer.) Vězda & CH-Graubünden; 18.02.2014; LC-071 & 1067 & $512(18-322 ; 332-538)$ & KX132954 & LIFU045-16 \\
\hline 3 & Arthrosporum populorum A. Massal. & CH-Valais; 06.02.2014; LC-046 & 586 & & KX132986 & LIFU078-16 \\
\hline 4 & Bacidia rubella (Hoffm.) A. Massal. & CH-Valais; 06.02.2014; LC-041 & 774 & $216(26-241)$ & KX132984 & LIFU076-16 \\
\hline 5 & Bacidia vermifera (Nyl.) Th. Fr. & CH-Bern; 04.07.2012; RE-515-19 & 578 & & KX132992 & LIFU084-16 \\
\hline 6 & Bacidina arnoldiana aggr.* & CH-Lucerne; 30.03.2011; BC-038-1 & 583 & & KX132958 & LIFU049-16 \\
\hline 7 & Bacidina arnoldiana aggr.* & CH-Zurich; 15.07.2011; BC-132-1 & 795 & $213(26-238)$ & KX132972 & LIFU063-16 \\
\hline 8 & Bryoria capillaris (Ach.) Brodo \& D. Hawksw. & CH-Bern; 06.02.2014; LC-058 & 803 & $223(26-248)$ & KX132945 & LIFU036-16 \\
\hline 9 & Buellia arborea Coppins \& Tønsberg & CH-Obwalden; 13.08.2011; BC-154-2 & 584 & & KX132975 & LIFU066-16 \\
\hline 10 & Bunodophoron melanocarpum (Sw.) Wedin & CH-Bern; 06.02.2014; LC-065 & 584 & & KX132949 & LIFU040-16 \\
\hline 11 & Cetrelia monachorum (Zahlbr.) W.L. Culb. \& C.F. Culb. & CH-Lucerne; 22.02.2014; KM-03-07 & 577 & & KX132924 & LIFU015-16 \\
\hline 12 & Chaenotheca cf. stemonea (Ach.) Müll. Arg. & CH-Neuchâtel; 13.05.2011; BC-087-3 & 571 & & KX133006 & LIFU098-16 \\
\hline 13 & Cladonia chlorophaea (Flörke ex Sommerf.) Spreng. & CH-Zurich; 01.02.2014; KM-01-8 & 872 & $227(26-252)$ & KX132914 & LIFU005-16 \\
\hline 14 & Cladonia coniocraea (Flörke) Spreng. & CH-Bern; 06.02.2014; LC-068 & 868 & $226(26-251)$ & KX132951 & LIFU042-16 \\
\hline 15 & Cladonia digitata (L.) Hoffm. & CH-Bern; 06.02.2014; LC-067 & 650 & & KX132950 & LIFU041-16 \\
\hline 16 & Cladonia squamosa (Scop.) Hoffm. & CH-Bern; 06.02.2014; LC-069 & 873 & $227(26-252)$ & KX132952 & LIFU043-16 \\
\hline 17 & Evernia divaricata (L.) Ach. & CH-Bern; 06.02.2014; LC-057 & 585 & & KX132944 & LIFU035-16 \\
\hline 18 & Evernia prunastri (L.) Ach. & CH-Graubünden; 18.02.2014; LC-070 & 578 & & KX132953 & LIFU044-16 \\
\hline 19 & Fellhanera bouteillei (Desm.) Vězda & CH-Lucerne; 03.2014; LC-118 & 609 & & KX132990 & LIFU082-16 \\
\hline 20 & Flavoparmelia caperata (L.) Hale & CH-Zurich; 15.02.2014; KM-02-02 & 1176 & $594(26-619)$ & KX132916 & LIFU007-16 \\
\hline 21 & Frutidella pullata (Norman) Schmull & CH-Bern; 17.05.2011; BC-115-2 & 828 & $232(26-257)$ & KX132970 & LIFU061-16 \\
\hline 22 & Fuscidea arboricola Coppins \& Tønsberg & CH-Vaud; 10.03.2007; BC-185-5 & n.a. & & KX132962 & LIFU053-16 \\
\hline 23 & Fuscidea pusilla Tønsberg & CH-St. Gallen; 20.04.2011; BC-063-2 & 542 & & & LIFU072-16 ${ }^{a}$ \\
\hline 24 & $\begin{array}{l}\text { Hyperphyscia adglutinata (Flörke) H. Mayrhofer } \\
\text { \& Poelt }\end{array}$ & CH-St. Gallen; 11.04.2011; BC-055-3 & 795 & $228(26-253)$ & KX132959 & LIFU050-16 \\
\hline 25 & Hypocenomyce scalaris (Ach. ex Lilj.) M. Choisy & CH-Valais; 06.02.2014; LC-016 & 564 & & KX132982 & LIFU074-16 \\
\hline 26 & Hypogymnia farinacea Zopf & CH-Bern; 06.02.2014; LC-062 & 580 & & KX132947 & LIFU038-16 \\
\hline 27 & Hypogymnia physodes (L.) Nyl. & CH-Valais; 06.02.2014; LC-039 & 810 & $228(26-253)$ & KX132937 & LIFU028-16 \\
\hline 28 & Hypogymnia tubulosa (Schaer.) Hav. & CH-Jura; 01.03.2014; LC-107 & 797 & $220(26-245)$ & KX132956 & LIFU047-16 \\
\hline 29 & Hypotrachyna laevigata (Sm.) Hale & CH-Lucerne; 22.02.2014; KM-03-05 & 582 & & KX132922 & LIFU013-16 \\
\hline 30 & Lecania cf. cyrtella (Ach.) Th. Fr. & CH-Valais; 06.02.2014; LC-023 & 801 & $223(26-248)$ & KX132983 & LIFU075-16 \\
\hline 31 & Lecanora albella (Pers.) Ach. & CH-Bern; 17.05.2011; BC-118-1 & 590 & & KX133002 & LIFU094-16 \\
\hline 32 & Lecanora allophana f. sorediata Nyl. & CH-Valais; 07.05.2011; BC-72-3 & 813 & $223(26-248)$ & KX133001 & LIFU093-16 \\
\hline 33 & Lecanora argentata/subrugosa & CH-Bern; 17.05.2011; BC-118-2 & 598 & & KX133003 & LIFU095-16 \\
\hline 34 & Lecanora carpinea (L.) Vain. & CH-Valais; 16.04.2011; BC-58-3 & 840 & $248(26-273)$ & KX132999 & LIFU091-16 \\
\hline 35 & Lecanora horiza (Ach.) Röhl. & CH-St. Gallen; 11.04.2011; BC-54-3 & 591 & & KX132998 & LIFU090-16 \\
\hline 36 & Lecanora impudens Degel. & CH-St. Gallen; 11.04.2011; BC-49-1 & 813 & $223(26-248)$ & KX132996 & LIFU088-16 \\
\hline 37 & Lecanora muralis (Schreb.) Rabenh. & CH-Valais; 06.02.2014; LC-045 & 590 & & KX132985 & LIFU077-16 \\
\hline 38 & Lecanora praesistens Nyl. & CH-Bern; 20.05.2013; MG-076-49 & 833 & $231(26-256)$ & KX132991 & LIFU083-16 \\
\hline
\end{tabular}


Group I intron

No. Target taxon

Lecanora pulicaris (Pers.) Ach.

Lecanora saligna (Schrad.) Zahlbr.

Lecanora sp.*

Lecanora strobilina aggr.*

Lecanora subcarpinea Szatala

Lecanora varia (Hoffm.) Ach.

Lecidella albida Hafellner

Lecidella cf. elaeochroma (Ach.) M. Choisy

Lecidella cf. leprothalla (Zahlbr.) Knoph \& Leuckert

Lecidella flavosorediata

(V̌̌zda) Hertel \& Leuckert

$9 \quad$ Lecidella flavosorediata

(Vězda) Hertel \& Leuckert

Lecidella scabra (Taylor) Hertel \& Leuckert

Lecidella sp.*

Lepraria elobata Tønsberg

Lepraria jackii Tønsberg

Lepraria lobificans Nyl.

Lepraria rigidula (B. de Lesd.) Tønsberg

Lepraria vouauxii (Hue) R.C. Harris

Letharia vulpina (L.) Hue

Loxospora elatina (Ach.) A. Massal.

Loxospora elatina (Ach.) A. Massal.

Megalaria pulverea (Borrer) Hafellner \& E. Schreiner

Melanelixia fuliginosa subsp. glabratula (Lamy)

\section{J.R. Laundon}

62 Melanelixia glabra (Schaer.) O. Blanco, A. Crespo,

Divakar, Essl., D. Hawksw. \& Lumbsch

63 Melanelixia subargentifera (Nyl.) O. Blanco, A. Crespo,

Divakar, Essl., D. Hawksw. \& Lumbsch

64 Melanohalea exasperata (De Not) O. Blanco, A. Crespo,

Divakar, Essl., D. Hawksw. \& Lumbsch

65 Menegazzia terebrata (Hoffm.) A. Massal.

Micarea cinerea (Schaer.) Hedl.

Micarea xanthonica Coppins \& Tønsberg

Mycoblastus sanguinarius (L.) Norman

Parmelia saxatilis (L.) Ach.

Parmelia sulcata Taylor

Parmelina tiliacea (Hoffm.) Hale

72 Parmeliopsis ambigua (Wulfen) Nyl.
Collection data (site, date, ID)

CH-Jura; 01.03.2014; LC-101

CH-Glarus; 11.04.2011; BC-47-1

CH-Bern; 22.05.2011; BC-027-1

CH-Glarus; 11.04.2011; BC-52-1

CH-Bern; 01.03.2014; LC-090

CH-Zurich; 16.04.2011; BC-60-5

CH-St. Gallen; 20.04.2011; BC-067-3

CH-Graubünden; 18.02.2014; LC-072

CH-Neuchâtel; 13.05.2011; BC-077-2

CH-Valais; 08.05.2011; BC-074-14

CH-Bern; 01.03.2014; LC-091

595

808

590

592

599

599

597

CH-St. Gallen; 11.04.2011; BC-055-4

CH-Bern; 01.03.2014; LC-088

CH-Obwalden; 13.08.2011; BC-158-2

CH-Obwalden; 13.08.2011; BC-156-3

CH-Zurich; 18.07.2011; BC-133-3

CH-Valais; 16.04.2011; BC-056-2

CH-Zurich; 18.07.2011; BC-133-2

CH-Valais; 06.02.2014; LC-006

CH-Obwalden; 13.08.2011; BC-155-5

CH-Obwalden; 19.08.2011; BC-161-5

CH-Bern; 17.05.2011; BC-113-3

CH-Zurich; 01.02.2014; KM-01-6

CH-Valais; 06.02.2014; LC-043

CH-Valais; 06.02.2014; LC-042

CH-Valais; 06.02.2014; LC-028

CH-Bern; 06.02.2014; LC-054

CH-Lucerne; 22.02.2014; KM-03-03

CH-St. Gallen; 15.03.2011; BC-015-6

CH-Bern; 17.05.2011; BC-119-4

CH-Bern; 06.02.2014; LC-060

CH-Valais; 06.02.2014; LC-004

CH-Valais; 06.02.2014; LC-002
CH-Zurich; 01.02.2014; KM-01-4A ength (bp)

$226(26-251)$

206 (26-231)

$218(26-243)$

GenBank

No.

BOLD No.

KX132989

LIFU081-16

LIFU087-16

KX133005 LIFU097-16

KX132997 LIFU089-16

KX132988 LIFU080-16

KX133000 LIFU092-16

KX132987 LIFU079-16

KX132966 LIFU057-16

KX132965 LIFU056-16

KX132994 LIFU086-16

KX132960 LIFU051-16

KX132993 LIFU085-16

KX132978 LIFU069-16

KX132979 LIFU070-16

KX132974 LIFU065-16

KX132961 LIFU052-16

KX132973 LIFU064-16

KX132927 LIFU018-16

KX132976 LIFU067-16

KX133004 LIFU096-16

KX132969 LIFU060-16

KX132913 LIFU004-16

229 (26-254) KX132939 LIFU030-16

KX132938 LIFU029-16

KX132935 LIFU026-16

KX132943 LIFU034-16

KX132981 LIFU073-16

KX132957 LIFU048-16

KX132971 LIFU062-16

KX132946 LIFU037-16

KX132926 LIFU017-16

KX132912 LIFU003-16

KX132918 LIFU009-16

KX132923 


\begin{tabular}{|c|c|c|c|c|c|c|}
\hline No. & Target taxon & Collection data (site, date, ID) & $\begin{array}{l}\text { Barcode } \\
\text { length (bp) }\end{array}$ & $\begin{array}{l}\text { Group I intron } \\
\text { length (bp) } \\
\text { and position }\end{array}$ & $\begin{array}{l}\text { GenBank } \\
\text { No. }\end{array}$ & BOLD No. \\
\hline 73 & Parmotrema crinitum (Ach.) M. Choisy & CH-Lucerne; 22.02.2014; KM-03-06 & 609 & & KX132915 & LIFU006-16 \\
\hline 74 & Parmotrema perlatum (Huds.) M. Choisy & CH-Zurich; 14.02.2014; KM-02-01 & 610 & & KX132941 & LIFU032-16 \\
\hline 75 & Phaeophyscia ciliata (Hoffm.) Moberg & CH-Valais; 06.02.2014; LC-050 & 998 & $418(18-224 ; 233-443)$ & KX132942 & LIFU033-16 \\
\hline 76 & Phaeophyscia orbicularis (Neck.) Moberg & CH-Valais; 06.02.2014; LC-051 & 992 & $418(18-224 ; 233-443)$ & KX132940 & LIFU031-16 \\
\hline 77 & Phaeophyscia poeltii (Frey) Clauzade \& Cl. Roux & CH-Valais; 06.02.2014; LC-049 & 801 & $221(26-246)$ & KX132963 & LIFU054-16 \\
\hline 78 & Phlyctis argena (Spreng.) Flot. & CH-St. Gallen; 20.04.2011; BC-065-1 & 924 & $351(18-368)$ & KX132910 & LIFU001-16 \\
\hline 79 & Physcia adscendens (Fr.) H. Olivier & CH-Zurich; 01.02.2014; KM-01-2B & 784 & $222(26-247)$ & KX132934 & LIFU025-16 \\
\hline 80 & Physcia aipolia (Ehrh. ex Humb.) Fürnr. & CH-Valais; 06.02.2014; LC-026 & 783 & $216(26-241)$ & KX132933 & LIFU024-16 \\
\hline 81 & Physconia distorta (With.) J.R. Laundon & CH-Valais; 06.02.2014; LC-021 & 972 & $402(18-217 ; 226-427)$ & KX132967 & LIFU058-16 \\
\hline 82 & Placynthiella dasaea (Stirt.) Tønsberg & CH-Neuchâtel; 13.05.2011; BC-084-1 & 900 & $335(26-360)$ & KX132911 & LIFU002-16 \\
\hline 83 & Pleurosticta acetabulum (Neck.) Elix \& Lumbsch & CH-Zurich; 01.02.2014; KM-01-3A & 577 & & KX132925 & LIFU016-16 \\
\hline 84 & Pseudevernia furfuracea (L.) Zopf & CH-Valais; 06.02.2014; LC-001 & 574 & & KX132917 & LIFU008-16 \\
\hline 85 & Punctelia jeckeri (Roum.) Kalb & CH-Zurich; 15.02.2014; KM-02-03 & 901 & $336(26-361)$ & KX132977 & LIFU068-16 \\
\hline 86 & Pycnora sorophora (Vain.) Hafellner & CH-Obwalden; 13.08.2011; BC-156-1 & 565 & & KX132955 & LIFU046-16 \\
\hline 87 & Ramalina pollinaria (Westr.) Ach. & CH-Jura; 01.03.2014; LC-093 & 770 & $215(26-240)$ & KX133007 & LIFU099-16 \\
\hline 88 & Scoliciosporum umbrinum (Ach.) Arnold & CH-Valais; 06.02.2014; LC-024 & 598 & & KX133008 & LIFU100-16 \\
\hline 89 & Scoliciosporum umbrinum (Ach.) Arnold & CH-Bern; 16.05.2013; MG-114-3C & 598 & & KX132936 & LIFU027-16 \\
\hline 90 & Tuckermannopsis chlorophylla (Willd.) Hale & CH-Valais; 06.02.2014; LC-032 & 560 & & KX132929 & LIFU020-16 \\
\hline 91 & Usnea barbata (L.) Weber ex F.H. Wigg. & CH-Valais; 06.02.2014; LC-011 & 578 & & KX132932 & LIFU023-16 \\
\hline 92 & Usnea barbata (L.) Weber ex F.H. Wigg. & CH-Valais; 06.02.2014; LC-019 & 578 & & KX132921 & LIFU012-16 \\
\hline 93 & Usnea ceratina Ach. & CH-Lucerne; 22.02.2014; KM-03-04 & 578 & & KX132919 & LIFU010-16 \\
\hline 94 & Usnea intermedia (A. Massal.) Jatta & CH-Lucerne; 22.02.2014; KM-03-01 & 578 & & KX132920 & LIFU011-16 \\
\hline 95 & Usnea intermedia (A. Massal.) Jatta & CH-Lucerne; 22.02.2014; KM-03-02 & 578 & & KX132930 & LIFU021-16 \\
\hline 96 & Usnea lapponica Vain. & CH-Valais; 06.02.2014; LC-013 & 579 & & KX132928 & LIFU019-16 \\
\hline 97 & Usnea substerilis Motyka & CH-Valais; 06.02.2014; LC-009 & 577 & & KX132968 & LIFU059-16 \\
\hline 98 & Violella fucata (Stirt.) T. Sprib. & CH-Bern; 17.05.2011; BC-109-4 & 834 & $235(26-260)$ & KX132980 & LIFU071-16 \\
\hline 99 & Violella fucata (Stirt.) T. Sprib. & CH-Obwalden; 13.08.2011; BC-159-4 & 592 & & KX132931 & LIFU022-16 \\
\hline 100 & Vulpicida pinastri (Scop.) J.-E. Mattsson \& M.J. Lai & CH-Valais; 06.02.2014; LC-015 & 792 & $216(26-241)$ & KX132948 & LIFU039-16 \\
\hline
\end{tabular}

Note: The morphology and chemistry of the undescribed taxa marked with an asterisk $\left({ }^{*}\right)$ are discussed in text.

${ }^{a}$ No sequence, specimen data only. 
vegetative thallus, 1-2 apothecia were used for DNA extraction. Frozen lichen samples were lyophilized and disrupted with a stainless steel bead in a Retsch MM2000 mill (Düsseldorf, Germany) for $2 \mathrm{~min}$ at $30 \mathrm{~Hz}$. The full genomic DNA was extracted using the Qiagen DNEasy Plant Mini Kit (QIAGEN, Hilden, Germany) following the manufacturer's Plant Tissue Mini Protocol and diluted in $50 \mu \mathrm{L}$ elution buffer. A two-step polymerase chain reaction (PCR) approach was used for unidirectional amplicon sequencing. First, the full ITS was amplified via PCR by using short fungal-specific primers, ITS1F (Gardes and Bruns 1993) and ITS4 (White et al. 1990). Each PCR reaction $(25 \mu \mathrm{L})$ consisted of $2 \times$ KAPA HiFi HotStart ReadyMix PCR mix (KAPA Biosystems), $5 \mu \mathrm{mol} / \mathrm{L}$ of each of the forward and reverse primer, and $1 \mu \mathrm{L}$ of template DNA. Thermal cycle conditions included the initial denaturation at $95^{\circ} \mathrm{C}$ for $2 \mathrm{~min} ; 35$ cycles of denaturation for $20 \mathrm{~s}$ at $98^{\circ} \mathrm{C}$, primer annealing for $15 \mathrm{~s}$ at $57^{\circ} \mathrm{C}$, and extension for $20 \mathrm{~s}$ at $72{ }^{\circ} \mathrm{C}$; and final extension for $3 \mathrm{~min}$ at $72{ }^{\circ} \mathrm{C}$. The PCR products were visualized on $1.5 \%$ agarose gel and purified via Exo-SAP (Fermentas) treatment. In the second PCR step, the products were re-amplified with fulllength fusion primers designed by Microsynth AG (Balgach, Switzerland). The fusion primers contained the GS FLX Titanium A- and B-adapters of the kit Lib-L (Roche Diagnostics), the multiplex identifier (MID) sequence, four base library key sequence (TCAG), and the same sample-specific primers used in the first step. The MID tags were used only on the forward, A-adaptor for unidirectional sequencing. Amplifications were conducted in $50 \mu \mathrm{L}$ reaction volumes containing $39 \mu \mathrm{L}$ of mastermix with reagents $5 \times$ KAPA HiFi Buffer, $10 \mathrm{mmol} / \mathrm{L}$ KAPA dNTP Mix, 2U/100 $\mu$ L KAPA HiFi HotStart DNA Polymerase (KAPA HiFi HotStart PCR Kit, KAPA Biosystems), $4 \mu \mathrm{mol} / \mathrm{L}$ of each of the forward and reverse primer, and $1 \mu \mathrm{L}$ of template DNA. The cycle conditions were as follows: initial denaturation at $95{ }^{\circ} \mathrm{C}$ for $3 \mathrm{~min} ; 12$ cycles of denaturation at $98{ }^{\circ} \mathrm{C}$ for $20 \mathrm{~s}$, primer annealing at $56^{\circ} \mathrm{C}$ for $30 \mathrm{~s}$, and elongation at $72{ }^{\circ} \mathrm{C}$ for $30 \mathrm{~s}$; and a final elongation step at $72{ }^{\circ} \mathrm{C}$ for $5 \mathrm{~min}$. The aliquots were then purified via AMPure Beads XP (Beckman Coulter, Brea, Calif., USA). Concentrations of purified PCR products were quantified by fluorometry using the Quant-i $\mathrm{T}^{\mathrm{TM}}$ PicoGreen ${ }^{\circledR}$ dsDNA Assay Kit (Molecular Probes, Eugene, Oreg., USA). Probes were pooled in four equimolar pools (25 each), purified in $1.5 \%$ preparative gel, and run on 4/16 of a sequencing plate using Titanium FLX+ reagents on a GS Roche Sequencer (454 technology, Roche Diagnostics). Pre-sequencing steps (starting from the second PCR), sequencing, raw data processing using \#3 pipeline preconfigured by Roche for long amplicons, and sorting the resulting reads into samples based on their MID's (demultiplexing) were all carried out by Mircosynth AG.

\section{Data processing and analyses}

We followed a traditional and rather conservative approach when sorting and clustering sequences. Reads with a non-matching forward primer, that were shorter than $500 \mathrm{bp}$, included more than two ambiguous sites, and (or) with a mean quality score lower than 25 were disregarded using the programs Cutadapt v1.7 (Martin 2011) and PRINSEQ-lite v0.20.4 (Schmieder and Edwards 2011). The quality-sorted reads were screened for chimeras using the uchime_ref command in the sequence analysis tool USEARCH v8.0.1623 (Edgar et al. 2011), searching against the UNITE/INSDC reference database of fungal ITS sequences (Nilsson et al. 2015) available at http://unite.ut.ee/repository.php (accessed 26 July 2015). The sequence data were not denoised, and singleton sequences were included to better understand the artifactual and biological sequence variation. The remaining reads for each sample were sorted by length, then clustered with USEARCH at a $95 \%$ similarity threshold using the centroids function in the UCLUST algorithm (Edgar 2010). This approach assumes that the longest read of a cluster is the most appropriate and assures that the longest fragment of the full ITS marker will be used for downstream analyses. The less stringent clustering was opted for our data to compensate for a high sequence error rate in the 454 system and to better reflect biological units, based on preliminary analyses where the suggested $97 \%$ threshold (see Blaalid et al. 2013) was applied. The resulting centroid sequences were compared against the NCBI nucleotide database (NCBI Resource Coordinators 2013) using the blastn algorithm to obtain their initial taxonomic affiliations.

Even though the Roche GS FLX+ system is capable of sequencing fragments up to 1000-bp long, the average read length remains between 500 and 600 bp (Erguner et al. 2015). The quality of the barcodes becomes an issue towards the end of the read as the base-call quality drops, and the further away from the start, the more ambiguous the base calling becomes (Fig. 1). The full ITS region in fungi has an average length of $500 \mathrm{bp}$ in ascomycetes (Porter and Golding 2011). Based on the available sequences of the studied fungi, the barcoded ITS region is usually more than 550-bp long, and depending on the presence and length of the group I intron, it can be more than 1000-bp long. Consequently, ITS barcodes of more than 500-600 bp get fewer full-length target reads with low-quality sequence ends. Furthermore, various sequencing and PCR errors, such as homopolymer indel errors, CAFIE errors, and chimeras, are frequent and not always detected using the quality scores (reviewed in, for example, Margulies et al. 2005; Huse et al. 2007; Gilles et al. 2011; Lücking et al. 2014b).

To obtain a more reliable species reference sequence, the reads of the target taxon that were concordant with the quality parameters specified above were aligned using the MAFFT v7.017 automatic algorithm (Katoh and Standley 2013) in the Geneious v7.1.6 platform (Kearse et al. 2012). To gather the relevant sequences from a pool, we used the cluster identifications from a previous step. Sequences within the target species (the expected myco- 
Fig. 1. General overview of pyrosequencing reads, with (A) number of reads per sample, (B) average read length, and (C) read quality distribution over read length. [Colour online.]

A

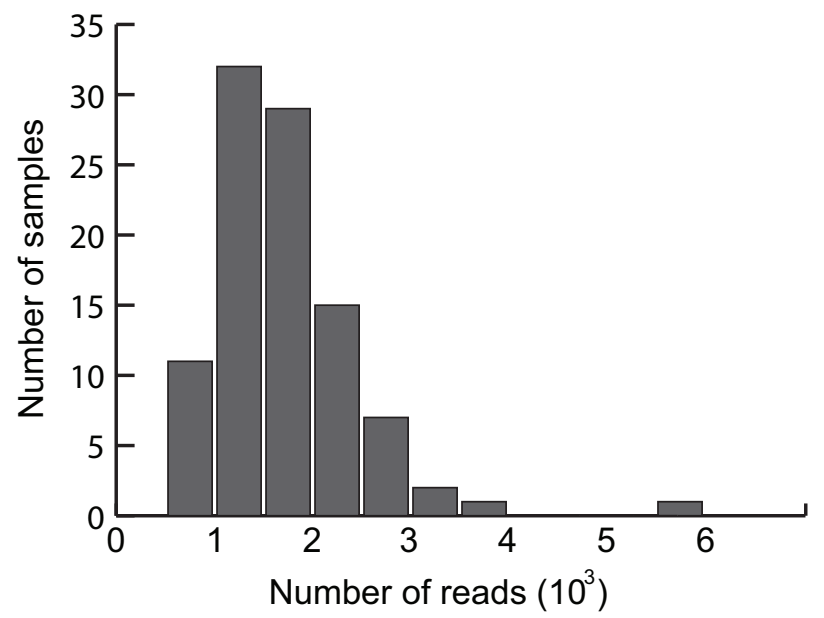

B

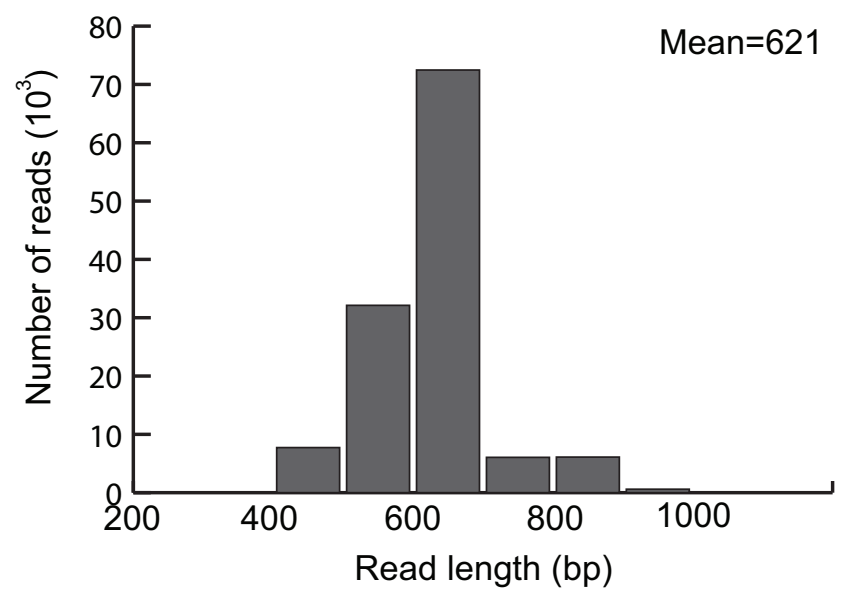

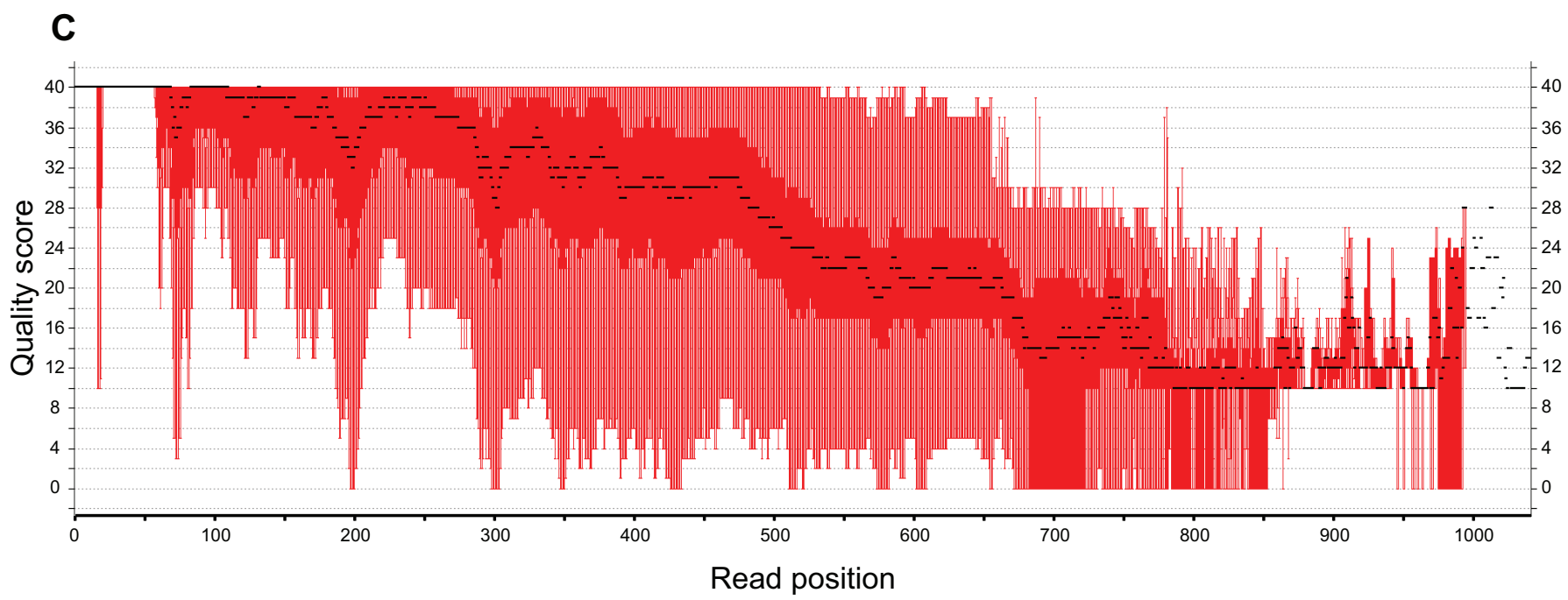

biont of the observed and determined lichen species) cluster(s) -identified as the taxon and (or) closely related taxon (for closely related species groups) using the GenBank BLAST function-were gathered and aligned together with reference sequences from GenBank. Clear outliers in the alignment were removed, the primer binding sites were trimmed, and the remaining regionincluding the end of ribosomal RNA gene 18S, ITS1, 5.8S rRNA gene, ITS2, the beginning of the 28S rRNA gene, and in some species, also the group I intron at the end of the $18 \mathrm{~S}$ gene-was designated as the barcode region for the species. Nucleotide diversity was estimated for alignments with removed reference sequences using DnaSP v5.10.1(Librado and Rozas 2009). The consensus sequence of this region was assigned as the barcode for this species. The barcode and the representative centroid sequence-the longest read of the biggest cluster of the taxon-were aligned using the same alignment function in MAFFT, to estimate sequence similarity and the quantity of indels and nucleotide differences. Using the consensus sequence approach allowed us to ignore much of the random noise within sequences, but it is dependent on the accuracy of a given alignment. Alternatively to MAFFT, we applied the PaPaRa alignment (Berger and Stamatakis 2011) to better account for erroneous insertions. Finally, however, PaPaRa alignments were not used due to multiple reasons, discussed and exemplified in the supplementary data, File $S 1^{2}$.

We tested the identification of the generated barcodes using the NCBI nucleotide database, currently the most 
complete database for lichen-forming fungi. The barcodes were compared against the database using the megaBLAST function in GenBank (http://www.ncbi.nlm. nih.gov/genbank/; accessed 11 January 2015; Madden 2002). To evaluate the success of specimen identification using DNA barcoding we only counted the identity of the best match in GenBank BLAST, ignoring the sequence similarity since no singe meaningful threshold can be applied over the species set, and for many of the taxa, too little or no information is known for accurate threshold estimation. We compared the morphological species determination with the best match (= with the highest bit score) from the barcode sequence megaBLAST search and recorded for each specimen if the identification via DNA barcoding resulted in concordant results at the species or the genus level (= correct species $/$ = correct genus but different species or species not present in the database), divergent (= different genus and species), or neutral results (= unidentified or uncultured fungus). In cases where the hypothesized identity differed from the GenBank match, or the similarity between the GenBank sequences and our sequence was less than $97 \%$ (following Blaalid et al. 2013), a phylogeny-based identification was used. To achieve this, available closely related representative ITS sequences of the same genus or species group (depending on the known information of the species phylogeny) were aligned with the barcode using the program MAFFT v7 (Katoh and Standley 2013), where the G-INS-i alignment algorithm (Katoh and Toh 2008) with $1 \mathrm{PAM} / \mathrm{K}=2$ scoring matrix was set. The alignments of ITS sequences were analyzed using a maximum likelihood (ML) criterion in the program RAxML v7.3.1 (Stamatakis 2006) where the evolutionary model was set to GTRGAMMA, and node support was assessed using 1000 "fastbootstrap" replicates (Stamatakis et al. 2008).

Where distinct nucleotide variation-possibly representing intragenomic variation of ITS sequences or a mixture of individuals of the same or closely related species-was noted, the target species alignments were studied carefully, and different ITS version frequencies were counted. In cases where (a) less-dominant version(s) of ITS was/were higher in frequency than $10 \%$ of the target reads, consensus barcode(s) for the less-dominant versions were also generated. The most frequent barcode version was assigned as the primary barcode for the specimen. The different barcode versions were aligned using the MAFFT v7.017 automatic algorithm (Katoh and Standley 2013), and sequence variation, nucleotide diversity, and distances (p-distances, with indels treated as missing data with pairwise deletion) were estimated using DnaSP v5.10.1 (Librado and Rozas 2009) and MEGA5 (Tamura et al. 2011). More distant barcodes of a samplepossibly resulting from a mixture of closely related species-were aligned with closely related representative ITS sequences (for the species list and references see Table $S 1^{2}$ ), and phylogenetic trees were constructed us- ing the ML approach executed with RAxML v7.3.1 as described above. In some samples, unalignable, up to 10-bp-long regions were detected. Since these regions were usually within or after GC-rich areas, we suspected a problematic PCR accompanied by CAFIE errors, rather than genuine mutations (Dutton et al. 1993). A known issue for GC-rich islands is knot formations in the RNA fold. The RNA secondary structure for such problematic regions was estimated using RNAstructure web servers (available at: http://rna.urmc.rochester.edu/RNAstructureWeb; accessed 18 November 2015) utilizing the default parameters (Bellaousov et al. 2013).

\section{Results}

The sequencing of 100 lichens resulted in 128449 reads. The number of reads per sample varied between 207 and 5473, with an average of 1285. A general overview of sequencing reads is given in Fig. 1. Through quality sorting and chimera checking, on average $21 \%$ of the reads were removed, varying from $9 \%$ to $57 \%$ among samples. Clustering of reads at $95 \%$ resulted in an average of 88 clusters per sample (minimum - mean \pm standard deviation - maximum; 5 - 88 \pm 57 - 231). Despite conservative quality sorting, high nucleotide variation per sample was present in the data. While a high proportion of variation resulted from contaminant fungi within samples, significant nucleotide variation within the target taxon was also present (Table 2). The mean number of clusters per target species was $8(0-8 \pm 7-32)$, and the average nucleotide diversity within a target was $0.01128 \pm$ 0.01862 . The pairwise identity between the consensus sequence (barcode) and centroid sequence of the biggest cluster was on average $98.5 \%$, with 9.65 as the mean number of differences per sequence pair. Comparing centroid sequences with consensus barcodes revealed a mean difference of $1.46 \%$. About $90 \%$ of the differences were insertions (69\%) and deletions (21\%) that were especially prominent towards the end of the sequences, while the rest were nucleotide substitutions or CAFIE errors.

From 100 samples, we were able to recover the fungal ITS sequence of the lichen mycobiont for all sequenced species except one. Fuscidea arboricola sequences were not recovered in its sequence pool (\#22). Full barcodes, including the end of 18S rRNA, ITS1, 5.8S rRNA, ITS2, and the beginning $28 \mathrm{~S}$ rRNA, were generated for all species, except for the barcode of Anaptychia crinalis, which remained incomplete, with a partly missing ITS1 sequence due to two long group I introns towards the end of $18 \mathrm{~S}$ rDNA (altogether $512 \mathrm{bp}$ ). To recover the end of the barcode, chimeric sequences without the introns were used. Introns at the end of 18S rDNA were identified in 37 target taxa (Table 1). The length of the intron varied from 60 to $594 \mathrm{bp}$. The primary barcode sequences have been deposited in the NCBI and BOLD databases under the accession codes as indicated in Table 1 . All project dataspecimen voucher information, photographs, the complete 


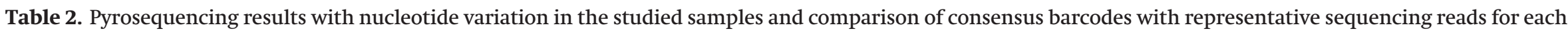
sample.

Comparison between consensus barcode and representative centroid

\begin{tabular}{|c|c|c|c|c|c|c|c|c|c|}
\hline No. & Species & Reads & Clusters $^{a}$ & $\begin{array}{l}\text { Reads of target } \\
\text { taxon (\%) }\end{array}$ & $\begin{array}{l}\text { Target } \\
\text { clusters }^{a}\end{array}$ & $\begin{array}{l}\text { Nucleotide } \\
\text { diversity } \pi\end{array}$ & $\begin{array}{l}\text { Pairwise } \\
\text { identity (\%) }\end{array}$ & $\begin{array}{l}\text { No of base } \\
\text { differences (\%) }\end{array}$ & TS/TV/Ind ${ }^{b}$ \\
\hline$\overline{1}$ & Alectoria sarmentosa & 582 & 28 & $463(79.6)$ & 1 & 0.00385 & 97.2 & $14(2.4)$ & $1 / 3 / 10$ \\
\hline 2 & Anaptychia crinalis & 342 & 70 & $52(15.2)$ & 3 & 0 & 98.6 & $9(1.4)$ & $0 / 0 / 9$ \\
\hline 3 & Arthrosporum populorum & 2937 & 78 & $2499(85.1)$ & 24 & 0.00433 & 98.0 & $12(2.0)$ & $0 / 0 / 12$ \\
\hline 4 & Bacidia rubella & 2194 & 38 & $2167(98.8)$ & 24 & 0.00643 & 98.6 & $11(1.4)$ & $0 / 0 / 11$ \\
\hline 5 & Bacidia vermifera & 4052 & 195 & $1813(44.7)$ & 24 & 0.00865 & 97.6 & $14(2.4)$ & $0 / 0 / 14$ \\
\hline 6 & Bacidina arnoldiana aggr. & 1715 & 231 & $116(6.8)$ & 8 & 0.03161 & 98.6 & $8(1.4)$ & $0 / 1 / 7$ \\
\hline 7 & Bacidina arnoldiana aggr. & 1406 & 185 & $100(7.1)$ & 4 & 0.01275 & 99.0 & $8(1.0)$ & $0 / 0 / 8$ \\
\hline 8 & Bryoria capillaris & 636 & 45 & $424(66.7)$ & 4 & 0.00811 & 98.5 & $12(0.5)$ & $2 / 2 / 8$ \\
\hline 9 & Buellia arborea & 891 & 98 & $281(31.5)$ & 8 & 0.00902 & 97.6 & $14(2.4)$ & $0 / 0 / 14$ \\
\hline 10 & Bunodophoron melanocarpum & 128 & 19 & $82(64.1)$ & 3 & 0.02226 & 98.0 & $12(2.0)$ & $0 / 0 / 12$ \\
\hline 11 & Cetrelia monachorum & 1903 & 93 & $1644(86.4)$ & 32 & 0.00487 & 97.6 & $14(2.4)$ & $0 / 1 / 13$ \\
\hline 12 & Chaenotheca cf. stemonea & 542 & 94 & $156(28.8)$ & 8 & 0.08548 & 99.3 & $4(0.7)$ & $2 / 0 / 2$ \\
\hline 13 & Cladonia chlorophaea & 1159 & 131 & $485(41.8)$ & 1 & 0.00099 & 98.9 & $10(1.1)$ & $0 / 0 / 10$ \\
\hline 14 & Cladonia coniocraea & 425 & 52 & $241(56.7)$ & 1 & 0.00274 & 98.9 & $10(1.2)$ & $0 / 0 / 10$ \\
\hline 15 & Cladonia digitata & 718 & 69 & $582(81.1)$ & 6 & 0.00195 & 97.5 & $16(2.5)$ & $0 / 2 / 14$ \\
\hline 16 & Cladonia squamosa & 291 & 82 & $159(54.6)$ & 1 & 0.0022 & 98.9 & $10(1.1)$ & $1 / 0 / 9$ \\
\hline 17 & Evernia divaricata & 472 & 48 & $366(77.5)$ & 5 & 0.0014 & 99.2 & $5(0.8)$ & $0 / 0 / 5$ \\
\hline 18 & Evernia prunastri & 382 & 55 & $112(29.3)$ & 8 & 0.00118 & 99.0 & $6(1.0)$ & $0 / 0 / 6$ \\
\hline 19 & Fellhanera bouteillei & 422 & 78 & $159(37.7)$ & 12 & 0.02398 & 99.7 & $2(0.3)$ & $0 / 0 / 2$ \\
\hline 20 & Flavoparmelia caperata & 553 & 109 & $42(7.6)$ & 9 & 0.00442 & 97.9 & $19(2.1)$ & $0 / 1 / 18$ \\
\hline 21 & Frutidella pullata & 841 & 161 & $31(3.7)$ & 3 & 0.00283 & 98.9 & $9(1.1)$ & $1 / 0 / 8$ \\
\hline 22 & Fuscidea arboricola & 1369 & 180 & 0 & 0 & - & - & - & $-1-1-$ \\
\hline 23 & Fuscidea pusilla & 1568 & 165 & $411(26.2)$ & 3 & 0.00409 & 99.6 & $2(0.4)$ & $1 / 0 / 1$ \\
\hline 24 & Hyperphyscia adglutinata & 1433 & 218 & $198(13.8)$ & 5 & 0.00389 & 99.5 & $4(0.5)$ & $0 / 0 / 4$ \\
\hline 25 & Hypocenomyce scalaris & 1446 & 34 & 1349 (93.3) & 8 & 0.00467 & 98.8 & $7(1.2)$ & $1 / 2 / 4$ \\
\hline 26 & Hypogymnia farinacea & 752 & 33 & $621(82.6)$ & 4 & 0.00097 & 97.0 & $18(3.0)$ & $0 / 1 / 17$ \\
\hline 27 & Hypogymnia physodes & 806 & 57 & $615(76.3)$ & 2 & 0.00352 & 97.7 & $19(2.3)$ & $2 / 1 / 16$ \\
\hline 28 & Hypogymnia tubulosa & 716 & 43 & $532(74.4)$ & 2 & 0.00219 & 98.0 & $16(2.0)$ & $0 / 0 / 16$ \\
\hline 29 & Hypotrachyna laevigata & 1137 & 92 & $867(76.3)$ & 16 & 0.00145 & 99.1 & $5(0.9)$ & $0 / 0 / 5$ \\
\hline 30 & Lecania cf. cyrtella & 728 & 78 & $413(56.7)$ & 7 & 0.02063 & 98.0 & $16(2.0)$ & $0 / 0 / 16$ \\
\hline 31 & Lecanora albella & 267 & 11 & $12(4.5)$ & 3 & 0.11882 & 77.7 & $118(19.9)^{*}$ & $26 / 47 / 45$ \\
\hline 32 & Lecanora allophana $f$. sorediata & 1717 & 19 & $1397(81.4)$ & 3 & 0.00643 & 99.5 & $4(0.5)$ & $0 / 0 / 4$ \\
\hline 33 & Lecanora argentata/subrugosa & 625 & 24 & $553(88.5)$ & 13 & 0.01542 & 98.8 & $7(1.2)$ & $0 / 0 / 7$ \\
\hline 34 & Lecanora carpinea & 224 & 6 & $187(83.5)$ & 2 & 0.02157 & 99.5 & $4(0.5)$ & $0 / 0 / 4$ \\
\hline 35 & Lecanora horiza & 963 & 9 & $963(100)$ & 9 & 0.0019 & 98.5 & $9(1.5)$ & $1 / 0 / 8$ \\
\hline 36 & Lecanora impudens & 221 & 14 & $186(84.2)$ & 7 & 0.00799 & 99.4 & $5(0.6)$ & $1 / 1 / 3$ \\
\hline 37 & Lecanora muralis & 1231 & 97 & 737 (59.9) & 22 & 0.00641 & 99.3 & $4(0.7)$ & $0 / 0 / 4$ \\
\hline 38 & Lecanora praesistens & 773 & 19 & $127(16.4)$ & 1 & 0.00532 & 99.1 & $7(0.9)$ & $0 / 0 / 7$ \\
\hline
\end{tabular}




\begin{tabular}{|c|c|c|c|c|c|c|c|c|c|}
\hline \multirow[b]{2}{*}{ No. } & \multirow[b]{2}{*}{ Species } & \multirow[b]{2}{*}{ Reads } & \multirow[b]{2}{*}{ Clusters $^{a}$} & \multirow[b]{2}{*}{$\begin{array}{l}\text { Reads of target } \\
\text { taxon (\%) }\end{array}$} & \multirow[b]{2}{*}{$\begin{array}{l}\text { Target } \\
\text { clusters }^{a}\end{array}$} & \multirow[b]{2}{*}{$\begin{array}{l}\text { Nucleotide } \\
\text { diversity } \pi\end{array}$} & \\
\hline & & & & & & & $\begin{array}{l}\text { Pairwise } \\
\text { identity (\%) }\end{array}$ & $\begin{array}{l}\text { No of base } \\
\text { differences (\%) }\end{array}$ & TS/TV/Ind ${ }^{b}$ \\
\hline 39 & Lecanora pulicaris & 379 & 10 & 347 (91.6) & 2 & 0.01427 & 99.0 & $8(1.0)$ & $0 / 0 / 8$ \\
\hline 40 & Lecanora saligna & 298 & 29 & $209(70.1)$ & 12 & 0.00692 & 99.0 & $6(1.0)$ & $0 / 0 / 6$ \\
\hline 41 & Lecanora sp. & 868 & 124 & $104(12)$ & 4 & 0.03276 & 99.0 & $7(1.0)$ & $3 / 0 / 4$ \\
\hline 42 & Lecanora strobilina aggr. & 269 & 11 & 247 (91.9) & 3 & 0.01246 & 98.5 & $9(1.5)$ & $0 / 0 / 9$ \\
\hline 43 & Lecanora subcarpinea & 1551 & 14 & $1390(89.6)$ & 7 & 0.00754 & 98.0 & $12(2.0)$ & $2 / 5 / 5$ \\
\hline 44 & Lecanora varia & 430 & 5 & $404(94)$ & 2 & 0.00386 & 98.9 & $9(1.1)$ & $2 / 0 / 7$ \\
\hline 45 & Lecidella albida & 1096 & 163 & $247(22.5)$ & 4 & 0.01403 & 97.7 & $14(2.3)$ & $0 / 1 / 13$ \\
\hline 46 & Lecidella cf. elaeochroma & 1215 & 58 & $1152(72.7)$ & 8 & 0.00403 & 99.2 & $5(0.8)$ & $1 / 0 / 4$ \\
\hline 47 & Lecidella cf. leprothalla & 1585 & 133 & 254 (20.9) & 5 & 0.00127 & 99.3 & $4(0.7)$ & $3 / 1 / 0$ \\
\hline 48 & Lecidella flavosorediata & 634 & 59 & $644(69.1)$ & 4 & 0.0462 & 98.7 & $8(1.3)$ & $0 / 0 / 8$ \\
\hline 49 & Lecidella flavosorediata & 932 & 76 & $214(33.8)$ & 2 & 0.00199 & 99.3 & $4(0.7)$ & $0 / 0 / 4$ \\
\hline 50 & Lecidella scabra & 2186 & 185 & $337(15.4)$ & 13 & 0.00193 & 97.7 & $14(2.3)$ & $2 / 0 / 12$ \\
\hline 51 & Lecidella sp. & 331 & 39 & $160(48.3)$ & 14 & 0.01223 & 99.7 & $2(0.3)$ & $0 / 0 / 2$ \\
\hline 52 & Lepraria elobata & 1134 & 194 & $197(17.4)$ & 22 & 0.0049 & 98.2 & $11(1.8)$ & $1 / 0 / 10$ \\
\hline 53 & Lepraria jackii & 960 & 166 & $161(16.8)$ & 18 & 0.00537 & 99.2 & $5(0.8)$ & $0 / 0 / 5$ \\
\hline 54 & Lepraria lobificans & 1021 & 212 & $349(34.2)$ & 16 & 0.00497 & 99.3 & $4(0.7)$ & $1 / 0 / 3$ \\
\hline 55 & Lepraria rigidula & 704 & 184 & $144(20.5)$ & 13 & 0.01333 & 99.2 & $5(0.8)$ & $0 / 0 / 5$ \\
\hline 56 & Lepraria vouauxii & 744 & 90 & 312 (41.9) & 7 & 0.00822 & 98.8 & $7(1.2)$ & $0 / 0 / 7$ \\
\hline 57 & Letharia vulpina & 621 & 19 & $574(92.4)$ & 7 & 0.0011 & 98.1 & $11(1.9)$ & $0 / 0 / 11$ \\
\hline 58 & Loxospora elatina & 722 & 90 & $291(40.3)$ & 13 & 0.01002 & 98.9 & $6(1.1)$ & $0 / 0 / 6$ \\
\hline 59 & Loxospora elatina & 3077 & 60 & $2713(88.2)$ & 23 & 0.00785 & 99.1 & $5(0.9)$ & $0 / 0 / 5$ \\
\hline 60 & Megalaria pulverea & 1516 & 198 & $290(19.1)$ & 9 & 0.01208 & 99.6 & $2(0.4)$ & $0 / 0 / 2$ \\
\hline 61 & Melanelixia fuliginosa subsp. glabratula & 975 & 163 & $294(30.2)$ & 4 & 0.00344 & 97.7 & $19(2.3)$ & $0 / 0 / 19$ \\
\hline 62 & Melanelixia glabra & 890 & 96 & $476(53.5)$ & 10 & 0.00457 & 98.3 & $10(1.7)$ & $0 / 0 / 10$ \\
\hline 63 & Melanelixia subargentifera & 698 & 58 & $478(68.5)$ & 3 & 0.00111 & 99.3 & $4(0.7)$ & $0 / 0 / 4$ \\
\hline 64 & Melanohalea exasperata & 891 & 85 & $330(37)$ & 3 & 0.00361 & 99.0 & $8(1.0)$ & $1 / 0 / 7$ \\
\hline 65 & Menegazzia terebrata & 926 & 94 & $672(72.6)$ & 20 & 0.00207 & 97.1 & $17(2.9)$ & $1 / 6 / 10$ \\
\hline 66 & Micarea cinerea & 422 & 32 & $341(80.8)$ & 4 & 0.00999 & 99.1 & $5(0.9)$ & $0 / 0 / 5$ \\
\hline 67 & Micarea xanthonica & 711 & 87 & $373(52.5)$ & 7 & 0.00728 & 99.3 & $5(0.7)$ & $0 / 0 / 5$ \\
\hline 68 & Mycoblastus sanguinarius & 824 & 102 & $222(26.9)$ & 3 & 0.00246 & 98.8 & $6(1.0)$ & $0 / 0 / 6$ \\
\hline 69 & Parmelia saxatilis & 362 & 58 & $241(66.6)$ & 1 & 0.00159 & 96.9 & $18(3.1)$ & $0 / 3 / 15$ \\
\hline 70 & Parmelia sulcata & 753 & 143 & $400(53.1)$ & 21 & 0.00604 & 98.0 & $11(1.8)$ & $0 / 0 / 11$ \\
\hline 71 & Parmelina tiliacea & 1391 & 133 & $1031(74.1)$ & 18 & 0.00203 & 99.0 & $6(1.0)$ & $1 / 0 / 5$ \\
\hline 72 & Parmeliopsis ambigua & 1401 & 89 & $878(62.7)$ & 7 & 0.00294 & 98.1 & $11(2.1)$ & $1 / 0 / 10$ \\
\hline 73 & Parmotrema crinitum & 1284 & 83 & 1146 (89.3) & 15 & 0.0023 & 98.4 & $10(1.6)$ & $0 / 1 / 9$ \\
\hline 74 & Parmotrema perlatum & 1981 & 112 & $1234(62.3)$ & 17 & 0.00143 & 98.2 & $11(1.8)$ & $0 / 0 / 11$ \\
\hline 75 & Phaeophyscia ciliata & 365 & 86 & $90(24.7)$ & 3 & 0.00115 & 98.2 & $17(1.8)$ & $0 / 0 / 17$ \\
\hline 76 & Phaeophyscia orbicularis & 407 & 92 & $83(20.4)$ & 2 & 0.01161 & 99.4 & $5(0.6)$ & $0 / 0 / 5$ \\
\hline 77 & Phaeophyscia poeltii & 756 & 71 & $423(56)$ & 3 & 0.00104 & 97.9 & $17(2.1)$ & $0 / 0 / 17$ \\
\hline
\end{tabular}


Comparison between consensus barcode

and representative centroid

\begin{tabular}{|c|c|c|c|c|c|c|c|c|c|}
\hline \multirow[b]{2}{*}{ No. } & \multirow[b]{2}{*}{ Species } & \multirow[b]{2}{*}{ Reads } & \multirow[b]{2}{*}{ Clusters $^{a}$} & \multirow[b]{2}{*}{$\begin{array}{l}\text { Reads of target } \\
\text { taxon (\%) }\end{array}$} & \multirow[b]{2}{*}{$\begin{array}{l}\text { Target } \\
\text { clusters }^{a}\end{array}$} & \multirow[b]{2}{*}{$\begin{array}{l}\text { Nucleotide } \\
\text { diversity } \pi\end{array}$} & \\
\hline & & & & & & & $\begin{array}{l}\text { Pairwise } \\
\text { identity (\%) }\end{array}$ & $\begin{array}{l}\text { No of base } \\
\text { differences (\%) }\end{array}$ & TS/TV/Ind ${ }^{b}$ \\
\hline 78 & Phlyctis argena & 1078 & 127 & $246(22.8)$ & 3 & 0 & 99.1 & $8(0.9)$ & $0 / 0 / 8$ \\
\hline 79 & Physcia adscendens & 962 & 111 & $474(49.3)$ & 29 & 0.04417 & 98.5 & $12(1.5)$ & $0 / 0 / 12$ \\
\hline 80 & Physcia aipolia & 612 & 73 & $377(61.6)$ & 4 & 0.002 & 98.6 & $11(1.4)$ & $0 / 0 / 11$ \\
\hline 81 & Physconia distorta & 1081 & 182 & 183 (16.9) & 3 & 0.04149 & 98.2 & $17(1.8)$ & $0 / 0 / 17$ \\
\hline 82 & Placynthiella dasaea & 1089 & 133 & $179(16.4)$ & 5 & 0.00495 & 99.1 & $8(0.9)$ & $1 / 0 / 7$ \\
\hline 83 & Pleurosticta acetabulum & 585 & 134 & $20(3.4)$ & 14 & 0.05287 & 99.1 & $5(0.9)$ & $1 / 2 / 2$ \\
\hline 84 & Pseudevernia furfuracea & 1017 & 27 & $879(86.4)$ & 9 & 0.0017 & 95.7 & $25(4.3)^{*}$ & $9 / 7 / 9$ \\
\hline 85 & Punctelia jeckeri & 499 & 79 & $107(21.4)$ & 2 & 0.07591 & 99.4 & $5(0.6)$ & $0 / 0 / 5$ \\
\hline 86 & Pycnora sorophora & 984 & 112 & $351(35.7)$ & 8 & 0.01008 & 98.9 & $6(1.1)$ & $0 / 0 / 6$ \\
\hline 87 & Ramalina pollinaria & 705 & 22 & $654(92.8)$ & 9 & 0.00525 & 98.5 & $12(1.5)$ & $1 / 0 / 11$ \\
\hline 88 & Scoliciosporum umbrinum & 1244 & 101 & $8(1.4)$ & 5 & 0.05371 & 99.5 & $4(0.7)$ & $0 / 1 / 3$ \\
\hline 89 & Scoliciosporum umbrinum & 592 & 201 & $148(11.9)$ & 3 & 0.01479 & 99.0 & $6(1.0)$ & $0 / 0 / 6$ \\
\hline 90 & Tuckermannopsis chlorophylla & 347 & 72 & $146(42.1)$ & 5 & 0.0035 & 97.6 & $14(2.4)$ & $0 / 0 / 14$ \\
\hline 91 & Usnea barbata & 1498 & 39 & $1269(84.7)$ & 10 & 0.00258 & 97.8 & $13(2.2)$ & $0 / 1 / 12$ \\
\hline 92 & Usnea barbata & 2202 & 51 & $2101(95.4)$ & 11 & 0.00209 & 96.8 & $19(3.2)$ & $0 / 4 / 15$ \\
\hline 93 & Usnea ceratina & 2627 & 69 & 2518 (95.9) & 14 & 0.00213 & 97.0 & $18(3.0)$ & $0 / 1 / 17$ \\
\hline 94 & Usnea intermedia & 2152 & 59 & $2009(93.4)$ & 2 & 0.00355 & 97.6 & $14(2.4)$ & $0 / 4 / 10$ \\
\hline 95 & Usnea intermedia & 1536 & 70 & $1287(83.8)$ & 5 & 0.00466 & 97.8 & $13(2.2)$ & $0 / 0 / 13$ \\
\hline 96 & Usnea lapponica & 1585 & 50 & $1463(92.3)$ & 14 & 0.00311 & 96.3 & $22(3.7)$ & $0 / 1 / 21$ \\
\hline 97 & Usnea substerilis & 868 & 38 & $700(80.6)$ & 7 & 0.00205 & 97.8 & $11(1.9)$ & $0 / 1 / 10$ \\
\hline 98 & Violella fucata & 830 & 93 & $134(16.1)$ & 4 & 0.02164 & 98.6 & $12(1.4)$ & $0 / 0 / 12$ \\
\hline 99 & Violella fucata & 1780 & 122 & $646(36.3)$ & 7 & 0.00704 & 99.7 & $2(0.3)$ & $0 / 0 / 2$ \\
\hline 100 & Vulpicida pinastri & 874 & 93 & $387(44.3)$ & 9 & 0.00159 & 98.9 & $9(1.1)$ & $1 / 0 / 8$ \\
\hline
\end{tabular}

Note: Asterisk (*) denotes chimeric representative centroid.

${ }^{a}$ Clustering conducted at $95 \%$ using centroids function in USEARCH.

${ }^{b}$ Quantity of transitions (TS), transversions (TV), and indels (Ind) between the generated consensus sequence (barcode) and representative centroid. 
Fig. 2. Comparison of morphological species determination and the results from sequence megaBLAST search in the NCBI nucleotide database for the studied 100 species. Only the best match accession identy was considered, and the sequence similarity results were ignored. Diagram proportions are indicated for concordant results at the species or the genus level (= correct species / = correct genus but different species or species not present), divergent (= different genus and species), or neutral results (= unidentified or uncultured fungus). For one species, no sequences were recovered within the quality-sorted reads; this is noted as "no target".

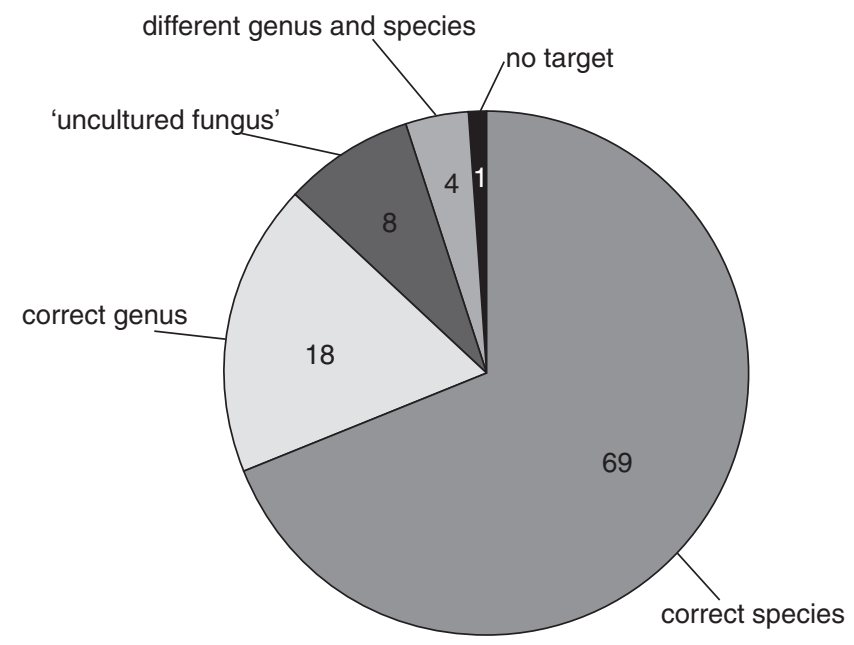

list of the barcode sequences (including the alternative versions), alignment matrices, phylogenetic trees - can be accessed though the PlutoF cloud database under project "Barcoding Swiss lichens using 454 pyrosequencing” (https:// plutof.ut.ee/\#/study/view/31890).

The barcodes from the targeted lichenized fungi were, in most cases, morphologically and molecularly identified to the same species $(n=69)$ or at least to the same genus $(n=18)$ using the NCBI nucleotide database as reference (Fig. 2; for details see Table $S 2^{2}$ ). Nine of the species correctly identified using GenBank BLAST showed less than $97 \%$ similarity, which could indicate wider ITS genetic variation of the species or even the presence of cryptic species. ITS sequences of 14 of the studied species were previously not available in GenBank, this being one of the reasons for imprecise identifications. For eight species, the best match in GenBank was an "uncultured fungus", originating from environmental metabarcoding studies where morphology-based identifications and taxonomic assignments are often not performed.

Nine samples were identified to the same genus but to a different species than that based on morphology, and one sample to a different genus based on a high identity score $(\geq 97 \%)$. These species were Anaptychia crinalis (identified as Anaptychia ciliaris, 98.0\%), Bryoria capillaris (identified as Bryoria fuscescens, 98.8\%), Lecanora impudens (identified as Lecanora allophana, 99.2\%), Loxospora elatina (identified as Loxospora ochrophaea, 99.7\%), Parmelia sulcata (identified as Myelochroa auruleanta, 99.7\%),
Parmotrema perlatum (identified as Parmotrema crinitum, 98.7\%), and Usnea barbata and Usnea substerilis (identified as Usnea intermedia/rigida, $>98.0 \%$ ). We found that these misidentifications had three main causes-(i) labelling or identification mistakes in the NCBI nucleotide database, as in the case of Parmelia sulcata; (ii) the incomplete reference database with missing species or partial sequences, as in the case of Anaptychia crinalis; (iii) biological reasons, such as low genetic variation in the ITS region (e.g., Bryoria capillaris, Parmotrema perlatum, Usnea barbata, and Usnea substerilis).

Besides the expected mycobiont, many other fungi were recovered within our samples. For 22 samples, the most-sequenced fungus was not the expected mycobiont but another fungus instead. Many of these fungi were identified as lichen-associated (facultative parasites/ lichenicolous) or plant-associated (epi- or endophytes). However, the lichen-associated fungal diversity within our sequenced lichens is not in the scope of the present study and will not be discussed further.

We studied the nucleotide variation of samples where (a) less frequent version(s) of ITS constituted more than $10 \%$ of the expected mycobiont reads. Multiple barcodes per species were generated for 22 samples (Table 3; for the full list of barcodes of such samples refer to Table $\mathrm{S}^{2}$ ). The number of generated barcodes, and distances between them, varied considerably from species to species. Barcode versions with only indels as differences showed zero distance (Buellia arborea, Cladonia digitata, Hypotrachyna laevigata). However, since the indels in these species were present in the non-coding regions (group I intron, ITS1, or ITS2), they cannot be completely ruled out as genuine mutations. In Lecanora subcarpinea, Lepraria lobificans, and Menegazzia terebrata, a poorly alignable, up to 10-bp-long region was detected in ITS1. These regions were positioned within or at the end of sequence regions with high $\mathrm{G}+\mathrm{C}$ content (GC\%), where formations of strong knots in RNA folds are likely. In Lecanora subcaripinea, a region of six ambiguous bases occured the end of a 38-bp region of 79.5\% GC content. In Lepraria lobificans, five ambiguous bases occured at the end of a 44-bp region with a GC\% of $82.6 \%$. In Menegazzia terebrata, in a 60 -bp region, with a GC\% of $86.0 \%$, an ambiguous region of nine bases occured within the sequencing reads. RNA secondary structure analyses revealed that the sequences in these areas form a secondary structure knot with probabilities of $>95 \%$ for Lecanora, $>99 \%$ for Lepraria, and $>99 \%$ for Menegazzia. Figure $\mathrm{S}^{2}$ shows, by way of example, the ITS1 RNA secondary structure of the primary barcode version and ambiguous bases of this region in Menegazzia terebrata barcodes.

The dominant ITS version of Physica adscendens is highly similar to sequences of this species (99\%; Table S2 ${ }^{2}$ ), while the second, less-frequent version included a high number of mostly unidirectional transitional mutations and was with low similarity to Physcia adscendens sequences (87\%). 
Table 3. List of samples where minor barcode version(s) constituted more than $10 \%$ of the target reads, with characteristics of nucleotide variation between the barcodes and comparison with available Sanger sequences of the species (where possible, otherwise marked with "-").

\begin{tabular}{|c|c|c|c|c|c|c|c|c|c|c|c|c|c|}
\hline \multirow[b]{2}{*}{ No. } & \multirow[b]{2}{*}{ Species } & \multirow{2}{*}{$\begin{array}{l}\text { No. of } \\
\text { Barcodes }\end{array}$} & \multirow{2}{*}{$\begin{array}{l}\text { Alignment } \\
\text { (bp) }\end{array}$} & \multirow{2}{*}{$\begin{array}{l}\text { Variable } \\
\text { sites }\end{array}$} & \multirow{2}{*}{$\begin{array}{l}\text { Nucleotide } \\
\text { diversity } \pi\end{array}$} & \multirow{2}{*}{$\begin{array}{l}\text { Max } \\
\text { distance }\end{array}$} & \multicolumn{6}{|c|}{ Quantity of base differences TS/TV/Ind ${ }^{b}$} & \multirow{2}{*}{$\begin{array}{l}\text { Same mutations } \\
\text { in Sanger }\end{array}$} \\
\hline & & & & & & & $18 \mathrm{~S}$ & Intron & ITS1 & $5.8 \mathrm{~S}$ & ITS2 & $28 S$ & \\
\hline 1 & Alectoria sarmentosa & 8 & 579 & 8 & 0.00795 & 0.016 & $0 / 0 / 0$ & n.a. & $0 / 4 / 1$ & $0 / 0 / 0$ & $1 / 4 / 2$ & $0 / 0 / 0$ & 0 \\
\hline 6 & Bacidina arnoldiana aggr. ${ }^{a}$ & 5 & 799 & 66 & 0.05519 & 0.087 & $0 / 0 / 0$ & n.a. & $7 / 1 / 1$ & $0 / 0 / 0$ & $7 / 0 / 1$ & $0 / 0 / 0$ & - \\
\hline 8 & Bryoria capillaris & 4 & 803 & 6 & 0.00498 & 0.008 & $0 / 0 / 0$ & $0 / 1 / 0$ & $2 / 1 / 0$ & $0 / 0 / 0$ & $2 / 0 / 0$ & $0 / 0 / 0$ & 3 \\
\hline 9 & Buellia arborea & 2 & 586 & 0 & 0 & 0 & $0 / 0 / 0$ & n.a. & $0 / 0 / 1$ & $0 / 0 / 0$ & $0 / 0 / 0$ & $0 / 0 / 0$ & - \\
\hline 12 & Chaenotheca cf. stemonea ${ }^{a}$ & 10 & 647 & 121 & 0.11473 & 0.253 & $0 / 0 / 0$ & $0 / 0 / 0^{c}$ & $2 / 0 / 0$ & $1 / 0 / 1$ & $3 / 1 / 3$ & $0 / 0 / 0$ & - \\
\hline 15 & Cladonia digitata & 4 & 650 & 0 & 0 & 0 & $0 / 0 / 0$ & n.a. & $0 / 0 / 0$ & $0 / 0 / 0$ & $0 / 0 / 3$ & $0 / 0 / 0$ & 0 \\
\hline 19 & Fellhanera bouteillei ${ }^{a}$ & 3 & 610 & 57 & 0.06421 & 0.102 & $0 / 0 / 0$ & n.a. & $3 / 1 / 0$ & $0 / 0 / 0$ & $1 / 1 / 0$ & $0 / 0 / 0$ & - \\
\hline 29 & Hypotrahyna laevigata & 2 & 583 & 0 & 0 & 0 & $0 / 0 / 0$ & n.a. & $0 / 0 / 0$ & $0 / 0 / 0$ & $0 / 0 / 1$ & $0 / 0 / 0$ & - \\
\hline 30 & Lecania cf. cyrtella & 2 & 802 & 25 & 0.03145 & 0.032 & $0 / 0 / 0$ & $6 / 5 / 1$ & $7 / 3 / 0$ & $1 / 0 / 1$ & $3 / 0 / 2$ & $0 / 0 / 3$ & - \\
\hline 43 & Lecanora subcarpinea & 18 & 597 & 7 & 0.00445 & 0.01 & $0 / 0 / 0$ & n.a. & $1 / 3 / 7$ & $0 / 0 / 0$ & $3 / 0 / 0$ & $0 / 0 / 0$ & 0 \\
\hline 50 & Lecidella scabra & 20 & 837 & 10 & 0.00987 & 0.024 & $0 / 0 / 0$ & $0 / 0 / 0^{c}$ & $7 / 3 / 1$ & $0 / 0 / 0$ & $3 / 1 / 1$ & $0 / 0 / 0$ & - \\
\hline 51 & Lecidella sp. & 9 & 597 & 13 & 0.01063 & 0.017 & $0 / 0 / 0$ & n.a. & $8 / 1 / 1$ & $0 / 0 / 0$ & $3 / 1 / 0$ & $0 / 0 / 0$ & - \\
\hline 54 & Lepraria lobificans & 6 & 565 & 4 & 0.00239 & 0.011 & $0 / 0 / 0$ & n.a. & $0 / 6 / 3$ & $0 / 0 / 0$ & $0 / 0 / 1$ & $0 / 0 / 0$ & 1 \\
\hline 55 & Lepraria rigidula & 6 & 601 & 13 & 0.00836 & 0.022 & $0 / 0 / 0$ & n.a. & $5 / 2 / 1$ & $0 / 0 / 0$ & $3 / 3 / 2$ & $0 / 0 / 0$ & 12 \\
\hline 64 & Melanohalea exasperata & 2 & 806 & 6 & 0.00752 & 0.008 & $0 / 0 / 0$ & $0 / 0 / 1$ & $3 / 1 / 1$ & $0 / 0 / 0$ & $2 / 0 / 3$ & $0 / 0 / 1$ & 5 \\
\hline 65 & Menegazzia terebrata & 16 & 592 & 16 & 0.00836 & 0.035 & $0 / 0 / 0$ & n.a. & $1 / 18 / 0$ & $3 / 6 / 6$ & $0 / 0 / 3$ & $0 / 0 / 0$ & 0 \\
\hline 69 & Parmelia saxatilis & 2 & 586 & 3 & 0.00515 & 0.005 & $0 / 0 / 0$ & n.a. & $0 / 0 / 0$ & $0 / 0 / 1$ & $0 / 3 / 3$ & $0 / 0 / 0$ & 0 \\
\hline 70 & Parmelia sulcata & 2 & 593 & 3 & 0.00506 & 0.005 & $0 / 0 / 0$ & n.a. & $2 / 0 / 0$ & $0 / 0 / 0$ & $1 / 0 / 0$ & $0 / 0 / 0$ & 2 \\
\hline 79 & Physcia adscendens & 2 & 790 & 92 & 0.11735 & 0.137 & $4 / 0 / 0$ & $32 / 0 / 0$ & $22 / 0 / 0$ & $9 / 0 / 0$ & $18 / 0 / 4$ & $7 / 0 / 2$ & 3 \\
\hline 86 & Pycnora sorophora & 2 & 565 & 4 & 0.00708 & 0.007 & $0 / 0 / 0$ & n.a. & $0 / 0 / 0$ & $0 / 0 / 0$ & $0 / 4 / 0$ & $0 / 0 / 0$ & 0 \\
\hline 95 & Usnea intermedia & 9 & 578 & 7 & 0.00596 & 0.01 & $0 / 0 / 0$ & n.a. & $1 / 2 / 0$ & $0 / 0 / 0$ & $2 / 2 / 0$ & $0 / 0 / 0$ & 4 \\
\hline 96 & Usnea lapponica & 6 & 579 & 8 & 0.00783 & 0.014 & $0 / 0 / 0$ & n.a. & $2 / 2 / 0$ & $0 / 0 / 0$ & $3 / 1 / 0$ & $0 / 0 / 0$ & 4 \\
\hline
\end{tabular}

Note: Nucleotide variation of specimens in bold more likely represents genuine mutations, while in others is probably due to PCR/sequencing errors.

${ }^{a}$ In presence of intraspecific variation, nucleotide variation within one of the "species" was compared: Bacidina arnoldiana subversions A1 \& A2, Chaenotheca cf. stemonea subversions A1, A2, B \& C, Fellhanera bouteillei subversions A1 \& A2 (for reference see Figs. 3-5).

${ }^{b}$ Quantity of transitions (TS), transversions (TV), and indels (Ind), divided into exons and introns.

'Variation in intron presence. 
However, no better alignment with any other sequence in GenBank was found. Altogether, 92 transitional mutations were present among the two ITS versions ( 4 in 18S, 32 in the group I intron, 22 in ITS1, 9 in 5.8S, 18 in ITS2, and 7 in 28S). These mutations were almost exclusively unidirectional, being mainly $\mathrm{G} \Rightarrow \mathrm{A}$ and $\mathrm{C} \Rightarrow \mathrm{T}$.

Besides artificial nucleotide variation caused by PCR/ sequencing errors, nucleotide variation can occur for biological reasons, such as (i) incomplete concerted evolution within the ITS and (ii) intraspecific variation. For 13 species, distinct nucleotide variation could not be explained by PCR or CAFIE errors only (Table 3). By comparing the variation within the reads of the mycobiont with available Sanger sequences from GenBank of the same species (where available), we also found the same variable bases in Sanger sequences in eight species. Therefore, it seems probable that intragenomic and (or) intra-mycelial (i.e., allelic heterozygosity) variation is present at least in the following samples: \#8 Bryoria capillaris, \#55 Lepraria rigidula, \#64 Melanohalea exasperata, \#70 Parmelia sulcata, \#79 Physcia adscendens, \#95 Usnea intermedia, and \#96 Usnea lapponica. For eight species, such comparisons could not be made due to a lack of Sanger sequences. Sequence variation possibly resulting from intragenomic or intra-mycelial variation were additionally detected in \#6 Bacidina arnoldiana, \#12 Chaenotheca cf. stemonea, \#19 Fellhanera bouteillei, \#30 Lecania cf. cyrtella, \#50 Lecidella scabra, and \#51 Lecidella sp., of which the first three are seemingly also accompanied with intraspecific variation (Figs. 3-5). The number of barcodes, however, might not necessarily represent the true intragenomic variation of a species. For example, seven variable nucleotide positions were found in Usnea intermedia with no clear segregation into distinct ITS types. In ITS1, three mutation positions $(\mathrm{G} \Leftrightarrow \mathrm{C}, \mathrm{T} \Leftrightarrow \mathrm{C}, \mathrm{T} \Leftrightarrow \mathrm{C}$ ) generated three types, while in ITS2, four mutation positions $(T \Leftrightarrow C, G \Leftrightarrow A$, $\mathrm{A} \Leftrightarrow \mathrm{C}, \mathrm{T} \Leftrightarrow \mathrm{A})$ generated four types, of which three were dominant. These types were combined with each, generating seven different barcode versions. Incomplete concerted evolution within ITS is therefore possible. However, inflation of ITS types should also be considered due to recombination or chimera formation between different ITS1 and ITS2 versions. The more similar the parents, the harder it is to detect and identify chimeras. Therefore, it could just as well be possible that fewer than seven different ITS versions are natural, while others are artificial formations. The number of barcodes can also be inflated by systematic CAFIE errors, which we have tried to account for when interpreting the reasons of base variation of some species (e.g., \#69 Parmelia saxatilis). For the full list of the alternative barcodes and their hypothetical origin refer to Table $\mathrm{S}^{2}$.

The highest number of variable sites, as well as the greatest genetic distances between barcodes, occurred in samples where multiple distinct lineages, probably representing different species, were identified in the pool.
These samples were crustose species Bacidina arnoldiana aggr., Chaenotheca cf. stemonea, and Fellhanera bouteillei.

In Bacidina arnoldiana aggr. (sample \#6), five different ITS versions from two Bacidina arnoldiana clades were identified (Fig. 4). The morphologically homogenous, yet variable species $B$. arnoldiana is therefore polyphyletic, comprising in itself multiple lineages and possibly other taxa with unresolved taxonomy. The five ITS versions from Bacidina arnoldiana belong in two major clusters, Bacidina arnoldiana 1 and Bacidina arnoldiana 3, and group together with other Bacidina arnoldiana sequences. Bacidina arnoldiana 2 includes only GenBank data and is more closely related to Bacidina arnoldiana 3. Four ITS versions cluster within Bacidina arnoldiana 1, of which two are dominant, $\mathrm{A} 1$ and $\mathrm{B} 1$. These are also almost equally present in the sequence pool (A1 in 65 reads, 42.6\%; B1 in 45 reads, 41.7\%). The subversions A1 and B1 have a pairwise identity of only $93.8 \%$, and based on genetic distances, clade Bacidina arnoldiana 1 could therefore include cryptic species. However, no final conclusions can be made of our limited sample size and data based on ITS markers only.

In Chaenotheca cf. stemonea (sample \#12), sequences from two Chaenotheca "species" were present(Fig. 5)—Chaenotheca cf. stemonea and Chaenotheca trichialis-xyloxena group. The first includes four highly similar (>98\%) barcodes differing in multiple mutations and in intron presence/absence towards the end of the 18S rDNA. The Chaenotheca trichialisxylogena group includes six barcodes that cluster further into three groups: versions B together with a subgroup of C. trichialis, version A1 clusters within C. xyloxena, and version A2 with a second subgroup of $C$. trichialis at the base of the clade. The distances within subversions $B$ are low (pairwise identity $>98 \%$ ), while between subversions $\mathrm{B}, \mathrm{A} 1$, and A2, distances are larger (pairwise identities between $96 \%$ and $97 \%$ ).

Fellhanera bouteillei (sample \#19) included three ITS versions, of which two highly similar types (identity 99\%), A1 and A2, were dominant, while the third, less-frequent version B was only present in three sequences. The lessdominant version is, however, significant as it represents the clade of Fellhanera beouteillei s.str. together with sequences available in GenBank (Fig. 5). The dominant types A1 and A2 clustered distantly outside of Fellhanera bouteillei and could represent a different species (pairwise identity between barcode versions A1 and B was $89 \%$ ).

\section{Discussion}

\section{Barcoding lichens}

In the scope of this study, we "barcoded" 99 out of 100 lichen mycobiont species using 454 pyrosequencing. Good success in generating barcodes shows the high potential of this method, especially concerning crustose lichens, which can be difficult to sequence with the Sanger technique. To our knowledge, this is the first attempt to apply pyrosequencing to lichen barcoding to such an extent. 
Fig. 3. Maximum likelihood ITS gene tree of available Bacidina arnoldiana aggr. sequences, with extended outgroup of closely related Bacidia species. Barcodes from Bacidina arnoldiana aggr. (sample \#6) are indicated with a shaded background. The number of reads per barcode is given in brackets at the end of the name. Branches leading to strongly supported nodes ( $\geq 70 \%)$ are marked in bold. The scale bar shows the number of substitutions per site. [Colour online.]

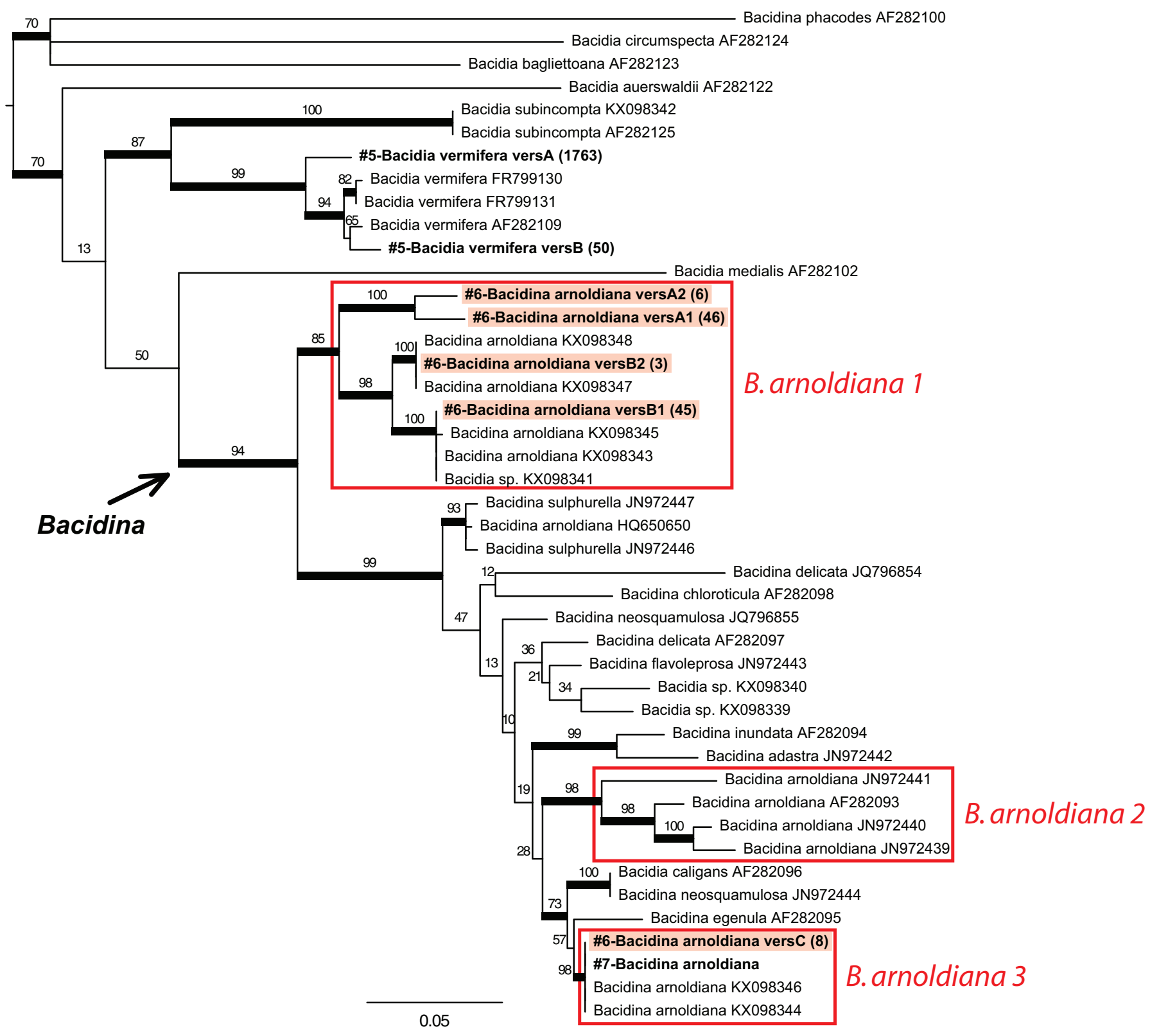

The success of DNA-based identification depends greatly on the reference database, both in the quality and quantity of the barcodes included. Purely DNA-based identification of lichens-without considering morphological and chemical characters-is far from reach, especially regarding crustose lichens and samples from poorly investigated regions due to missing references and unknown diversity (Orock et al. 2012). Within the present study, we generated ITS barcodes for 12 described species whose sequences were previously not available in GenBank and for two morphologically newly characterized specimens (\#41 Lecanora sp., \#51 Lecidella sp.). Multiple species showed low intraspecific ITS sequence similarity to other available sequences in GenBank (e.g., \#10 Bunodophoron melanocarpum, \#12 Chaenotheca cf. stemonea, \#19 Fellhanera bouteillei, \#30 Lecania cf. cyrtella, \#66 Micarea cinerea) or a high similarity to a different taxon (e.g., \#8 Bryoria capillaris, \#13-\#16 Cladonia species, \#36 Lecanora impudens, \#47 Lecidella cf. elaeochroma, \#47 Lecidella cf. leprothalla, \#58-\#59 Loxospora elatina, \#74 Parmotrema perlatum, \#91-\#92 Usnea barbata; refer to Table $\mathrm{S}^{2}$ and to the project in PlutoF for further information). Before specimen identification via DNA barcoding can be confidently applied, taxonomic studies in these groups are needed to confirm the species monophyly or, in cases of non-monophyly, propose segregation of a taxon into multiple species. However, our results also suggest that the NCBI nucleotide da- 
Fig. 4. Maximum likelihood ITS gene tree of available Chaenotheca sequences, including the barcodes from Chaenotheca cf. stemonea (sample \#12, all with shaded background). The number of reads per barcode is given in brackets at the end of the name. Branches leading to strongly supported nodes $(\geq 70 \%)$ are marked in bold. The scale bar shows the number of substitutions per site. [Colour online.]

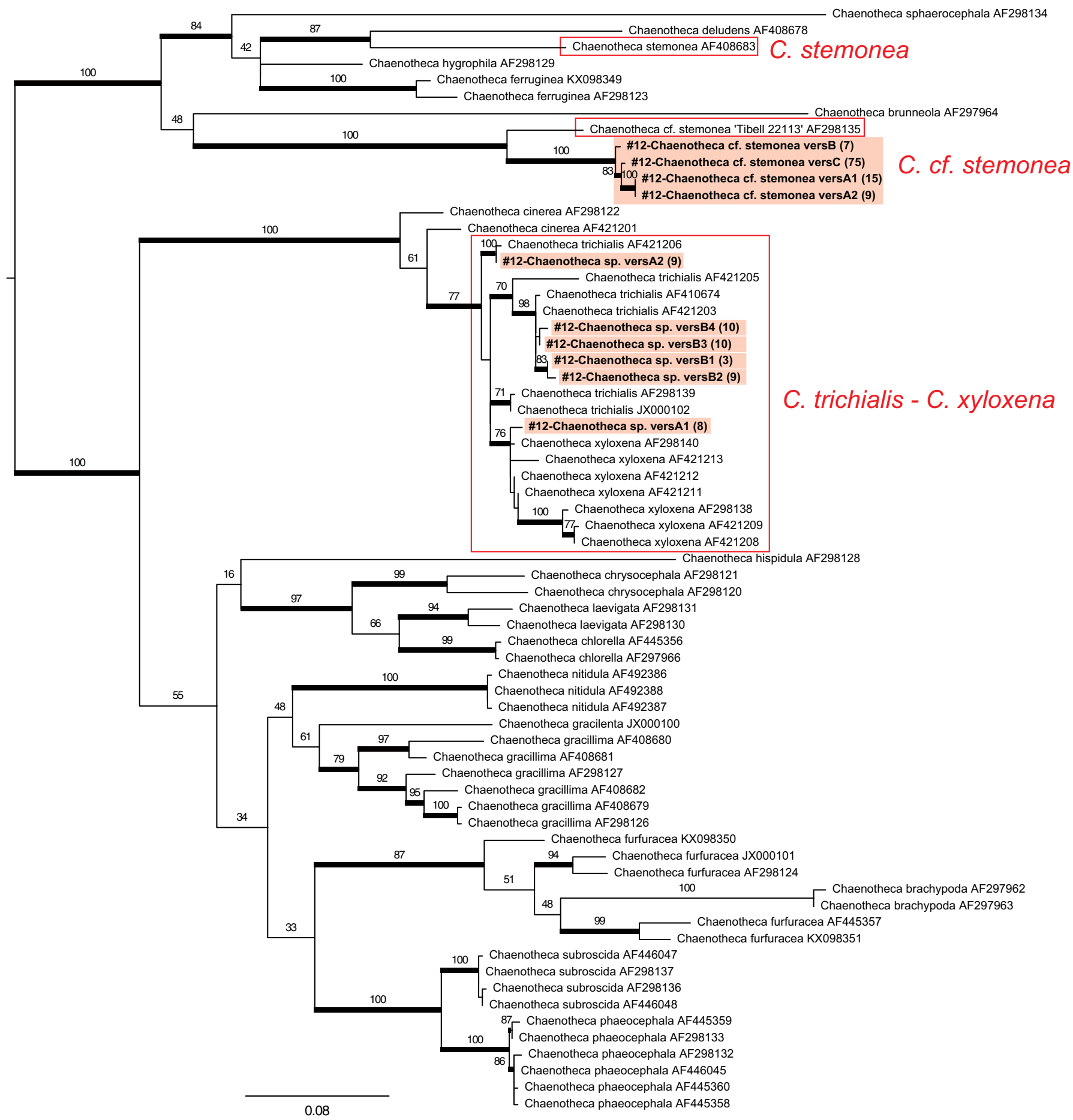

tabase, currently the most complete database for lichenforming fungi, could be used as a reference database to identify common species, as the majority of the analyzed lichens were identified correctly to the species or, at least, to the genus level.

When generating barcodes, we applied a rather conservative approach by generating consensus sequences from target taxon alignments, rather than using centroid sequences. In most cases, centroid reads were sufficiently accurate for correct specimen identification to a species level. However, when producing a barcode database, even a few errors can cause systemic mistakes in future identifications. Even though it is more time consuming, this approach helps to better identify and avoid 
Fig. 5. Maximum likelihood ITS gene tree of available Fellhanera sequences with extended outgroup of closely related species, including the barcodes from Fellhanera boutellei (sample \#19; all with shaded background). The number of reads per barcode is given in brackets at the end of the name. Branches leading to strongly supported nodes ( $\geq 70 \%)$ are marked in bold. The scale bar shows the number of substitutions per site. [Colour online.]

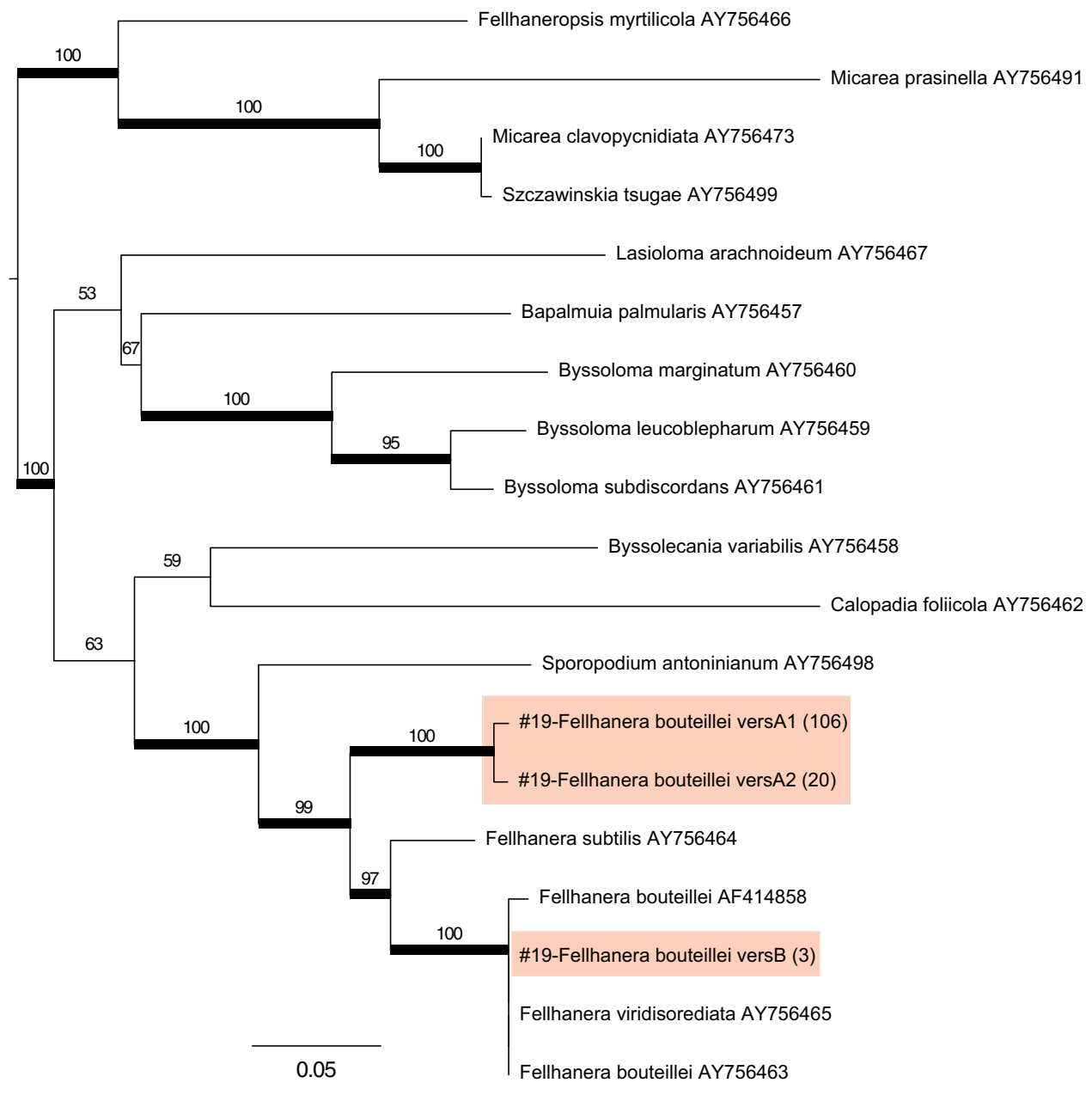

mistakes, such as those caused by sequencing, undetected chimeras, and multiple ITS copies. However, the propagation of errors cannot be avoided completely; they can originate directly from PCR amplification or be hindered by systematic sequencing errors, independent from data processing methods.

\section{Reasons for nucleotide variation}

The source of nucleotide variation within a species can be the PCR, the sequencing, or be of biological origin. While the first two sources generate artifactual variation, biological origins represent genuine mutations.

We identified three main sources of artifactual variation in our samples.

(1) Chimeras are hybrid products of PCR formed by different template sequences. Undetected chimeras lead to overestimated richness, artificial entities, and incorrect taxonomic identifications. It has been shown that chimera formation is especially strong in regions with alternating patterns between conserved and less-conserved regions, such as 16S rRNA genes (Shin et al. 2014). In the ITS barcodes-including conserved 18S, 5.8S, and 28S rRNA exons, alternating with variable ITS1 and ITS2 regions-frequent chimeras with switched ITS1 or ITS2 regions were observed (data not shown). Reads with group I intron towards the end of 18S rRNA gene often included chimeras where the intron had been excluded. Longer templates require longer extension times, which can contribute to chimera formation (Haas et al. 2011; Shin et al. 2014). Chimera detection is reasonably applicable in a closed system, where recombining gene variants are known. While the vast majority of fungal diversity is still unknown, chimeras should be considered as a real issue in diversity analyses where multiple templates are present in the pool (Sharifian 2010).

(2) High content of the nucleotides guanine and cytosine can impede amplification and result in lowquality sequencing with ambiguous bases. This difficulty is associated with poor denaturation of regions with high GC concentration, while template 
secondary structure hinders the access of PCR primers and enzyme work at elongation (Dutton et al. 1993). Even though high-temperature denaturation $\left(98^{\circ} \mathrm{C}\right)$ and high-fidelity heat-stable polymerase were used, the formation of strong knots in RNA structure that impede correct amplification cannot be ruled out and might have affected the ambiguous regions in the species Lecanora subcarpinea, Lepraria lobificans, and Menegazzia terebrata.

(3) 454 pyrosequencing is notorious for its high indel error rate in homopolymeric regions and carry-forwardincomplete-extension (CAFIE) errors (Margulies et al. 2005, Huse et al. 2007, Gilles et al. 2011). Incomplete extension creates shorter homopolymers due to insufficient dNTPs. Carry-forward errors are the result of incomplete dNTP flushing, which then causes a nucleotide from the end of the homoploymer to be read some bases later (e.g., a true sequence AAAATCG, can be read as AAATCGA). A comparison between the consensus barcodes and a representative read (the centroid sequence of the biggest cluster) showed a mean difference of $1.46 \%$. About $90 \%$ of the errors were indels. These were most prominent in homopolymeric regions and were especially frequent towards the end of the sequence, while the rest were nucleotide substitutions. Considering that in closely related species complexes, less than $2 \%$ variation could already result in a different identification, the necessity to reliably separate artificial from genuine variation becomes clear.

Nucleotide variation in the ITS can represent genuine mutations when a species is characterized by incomplete concerted evolution (Feliner and Rosselló 2007). We have highlighted 12 species in Table 3 where detected nucleotide variation could represent intragenomic variation within ITS, or alternatively, allelic heterozygosity caused by differing nuclei within a single mycelium (Huang et al. 2010; Hyde et al. 2013). The latter is more likely when only two primary allele variants in approximatly equal ratios are observed (Lindner et al. 2013). Two more or less equally represented ITS paralogs were found in \#1 Alectoria sarmentosa, \#6 Bacidina arnoldiana, \#8 Bryoria capillaris, \#43 Lecanora subcarpinea, and \#70 Parmelia sulcata, while one dominant ITS version together with relatively rare haplotypes was found in \#5 Bacidia vermifera, \#12 Chaenotheca cf. stemonea, \#19 Fellhanera bouteillei, \#30 Lecania cf. cyrtella, \#50 Lecidella scabra, \#51 Lecidella sp., \#55 Lepraria rigidula, \#64 Melanohalea exasperata, \#95 Usnea intermedia, and \#96 Usnea lapponica. The latter list includes representatives from a closely related species group in the genus Usnea (sect. Usnea; Mark et al. 2016), where low genetic variation and possible rapid radiation of species have been characterized (Truong et al. 2013; Kraichak et al. 2015). However, four other Usnea specimens from this closely related group were also included in our study, where such nucleotide variation was not detected (\#91-\#92 U. barbata, \#94 U. intermedia, and \#97 $U$. substerilis). Whether or not intragenomic variation can be detected via pyrosequencing likely also depends on the random effects of PCR and the proportions of different ITS copies in a genome.

Xu et al. (2009) demonstrated a high level of intraindividual polymorphism in rDNA, including multiple functional genes, putative pseudo genes, and recombinants. They also found a systematic bias in the efficiency with which different sequences were amplified. In Physcia adscendens, a second ITS version with unidirectional transitions from cytocine to thymine and adenine to guanine was detected. The second ITS version of this species could represent a rare divergent ITS allele or a pseudogene, propagated to a higher frequency due to a PCR bias. Ribosomal DNA pseudogenes are characterized by low stability in the predicted secondary structure, a higher substitution rate, and deamination-driven stubstitutions (Buckler et al. 1997). A large multigene family of 5S rRNA, including pseudogenes, has also been identified in other filamentous fungi (Margolin et al. 1998; Rooney and Ward 2005). A duplication event of the ribosomal DNA cistron could be a plausible explanation for the detected nucleotide variation in Physcia adscendens and is in concordance with the findings of Lücking et al. (2012).

Intraspecific variation, resulting from possible lichen chimeras or microcosms-where diverse communities live mixed and alongside-is illustrated by the phylogenies for three crustose species. For example, in a single sample of Bacidina, constituting a minute quantity of lichen soredia, four distinct lineages of Bacidina were identified in a visually inseparable community. In these species, the problem of distinguishing between intraand interspecific variation arises. This variation within a specimen cannot be detected in Sanger sequencing environmental samples, and this could be one of the reasons for the taxonomic mess in the Bacidina arnoldiana aggregate, as also illustrated in Fig. 4. Further studies with more data are needed to investigate such phenomena.

Whatever the reason, nucleotide variation detected through 454 pyrosequencing must be interpreted with caution, both with respect to the acquired barcode database as well as answering biological questions. Using other, less error-prone squencing platforms and (or) combining a large number of reads per taxon could help to avoid random sequencing errors. Sanger references can aid in distinguishing between CAFIE errors and biological sequence variation. However, Sanger sequencing may remain insufficient in some cases, as it is unable to detect intragenomic sequence variation (e.g., to investigate species and genome evolution) and fails to give useable results in a mixture of templates.

\section{Acknowledgements}

We thank Jean-Claude Walser from ETH Zurich Genetic Diversity Centre (GDC) for help with pyrosequencing data analyses and Microsynth AG for their collaboration. We 
also wish to thank the editor and the reviewers for their useful comments, and Curtis Gautschi for linguistic corrections. This study was funded by the Rectors' Conference of the Swiss Universities (CRUS) through the SCIEX-NMS ${ }^{\text {ch }}$ Scientific Exchange Programme (project SCIEX-LiCode), the Federal Office for the Environment (FOEN; grant to Silvia Stofer and C.S.), and SwissBOL (grant to C.S.).

\section{References}

Abarenkov, K., Henrik Nilsson, R., Larsson, K.Ä., Alexander, I.J., Eberhardt, U., Erland, S., et al. 2010. The UNITE database for molecular identification of fungi - recent updates and future perspectives. New Phytol. 186: 281-285. doi:10.1111/j.14698137.2009.03160.x. PMID:20409185.

Begerow, D., Nilsson, H., Unterseher, M., and Maier, W. 2010. Current state and perspectives of fungal DNA barcoding and rapid identification procedures. Appl. Microbiol. Biotechnol. 87: 99-108. doi:10.1007/s00253-010-2585-4. PMID:20405123.

Bellaousov, S., Reuter, J.S., Seetin, M.G., and Mathews, D.H. 2013. RNAstructure: web servers for RNA secondary structure prediction and analysis. Nucleic Acids Res. 41: W471-W474. doi:10.1093/nar/gkt290. PMID:23620284.

Bergamini, A., Scheidegger, C., Stofer, S., Carvalho, P., Davey, S., Dietrich, M., et al. 2005. Performance of macrolichens and lichen genera as indicators of lichen species richness and composition. Conserv. Biol. 19: 1051-1062. doi:10.1111/j.15231739.2005.00192.x-i1.

Berger, S.A., and Stamatakis, A. 2011. Aligning short reads to reference alignments and trees. Bioinformatics, 27(15): 20682075. doi:10.1093/bioinformatics/btr320. PMID:21636595.

Blaalid, R., Kumar, S., Nilsson, R.H., Abarenkov, K., Kirk, P.M., and Kauserud, H. 2013. ITS1 versus ITS2 as DNA metabarcodes for fungi. Mol. Ecol. Resour. 13: 218-224. doi:10.1111/1755-0998. 12065. PMID:23350562.

Buckler, E.S., Ippolito, A., and Holtsford, T.P. 1997. The evolution of ribosomal DNA divergent paralogues and phylogenetic implications. Genetics, 145: 821-832. PMID:9055091.

Clerc, P., and Truong, C. 2012. Catalogue des lichens de Suisse. Version 2.0, 11.06.2012. Available at: http://www.ville-ge.ch/ musinfo/bd/cjb/cataloguelichen.

Culberson, C.F., and Ammann, K. 1979. Standardmethode zur Dünnschichtchromatographie von Flechtensubstanzen. Herzogia, 5: 1-24.

Divakar, P.K., Leavitt, S.D., Molina, M.C., Del-Prado, R., Lumbsch, H.T., and Crespo, A. 2016. A DNA barcoding approach for identification of hidden diversity in Parmeliaceae (Ascomycota): Parmelia sensu stricto as a case study. Bot. J. Linn. Soc. 180(1): 21-29. doi:10.1111/boj.12358.

Dutton, C.M., Paynton, C., and Sommer, S.S. 1993. General method for amplifying regions of very high $\mathrm{G}+\mathrm{C}$ content. Nucleic Acids Res. 21: 2953-2954. doi:10.1093/nar/21.12.2953. PMID:8332515.

Edgar, R.C. 2010. Search and clustering orders of magnitude faster than BLAST. Bioinformatics, 26: 2460-2461. doi:10.1093/ bioinformatics/btq461. PMID:20709691.

Edgar, R.C., Haas, B.J., Clemente, J.C., Quince, C., and Knight, R. 2011. UCHIME improves sensitivity and speed of chimera detection. Bioinformatics, 27: 2194-2200. doi:10.1093/bioinformatics/ btr381. PMID:21700674.

Erguner, B., Ustek, D., and Sagiroglu, M.S. 2015. Performance comparison of Next Generation sequencing platforms. In 37th Annual International Conference of the IEEE, 2015, Engineering in Medicine and Biology Society (EMBC), Italy. pp. 6453-6456.

Feliner, G.N., and Rosselló, J.A. 2007. Better the devil you know? Guidelines for insightful utilization of nrDNA ITS in species- level evolutionary studies in plants. Mol. Phylogenet. Evol. 44: 911-919. PMID:17383902.

Feuerer, T., and Hawksworth, D.L. 2007. Biodiversity of lichens, including a world-wide analysis of checklist data based on Takhtajan's floristic regions. Biodivers. Conserv. 16: 85-98. doi:10.1007/s10531-006-9142-6.

Flück, D. 2012. DNA barcoding of Swiss epiphytic crustose lichens - a feasibility study. M.Sc. thesis, Academic Department, University of Bern, Bern, Switzerland.

Gardes, M., and Bruns, T.D. 1993. ITS primers with enhanced specificity for basidiomycetes - application to the identification of mycorrhizae and rusts. Mol. Ecol. 2: 113-118. doi:10. 1111/j.1365-294X.1993.tb00005.x. PMID:8180733.

Gilles, A., Meglécz, E., Pech, N., Ferreira, S., Malausa, T., and Martin, J.-F. 2011. Accuracy and quality assessment of 454 GS-FLX Titanium pyrosequencing. BMC Genomics, 12: 245. doi:10.1186/1471-2164-12-245. PMID:21592414.

Haas, B.J., Gevers, D., Earl, A.M., Feldgarden, M., Ward, D.V., Giannoukos, G., et al. 2011. Chimeric 16S rRNA sequence formation and detection in Sanger and 454-pyrosequenced PCR amplicons. Genome Res. 21: 494-504. doi:10.1101/gr.112730. 110. PMID:21212162.

Hodkinson, B., and Lendemer, J. 2013. Next-generation sequencing reveals sterile crustose lichen phylogeny. Mycosphere, 4: 1028-1039.

Huang, C., Xu, J., Gao, W., Chen, Q., Wang, H., and Zhang, J. 2010. A reason for overlap peaks in direct sequencing of rRNA gene ITS in Pleurotus nebrodensis. FEMS Microbiol. Lett. 305: 14-17. doi:10.1111/j.1574-6968.2010.01891.x. PMID:20148974.

Huse, S.M., Huber, J.A., Morrison, H.G., Sogin, M.L., and Welch, D.M. 2007. Accuracy and quality of massively parallel DNA pyrosequencing. Genome Biol. 8: R143. doi:10.1186/gb2007-8-7-r143. PMID:17659080.

Hyde, K.D., Udayanga, D., Manamgoda, D.S., Tedersoo, L., Larsson, E., Abarenkov, K., et al. 2013. Incorporating molecular data in fungal systematics: a guide for aspiring researchers. Curr. Res. Environ. Appl. Mycol. 3: 1-32.

Katoh, K., and Standley, D.M. 2013. MAFFT multiple sequence alignment software version 7: improvements in performance and usability. Mol. Biol. Evol. 30: 772-780. doi:10.1093/ molbev/mst010. PMID:23329690.

Katoh, K., and Toh, H. 2008. Recent developments in the MAFFT multiple sequence alignment program. Briefings Bioinf. 9: 286-298. doi:10.1093/bib/bbn013.

Kearse, M., Moir, R., Wilson, A., Stones-Havas, S., Cheung, M., Sturrock, S., et al. 2012. Geneious Basic: an integrated and extendable desktop software platform for the organization and analysis of sequence data. Bioinformatics, 28: 1647-1649. doi:10.1093/bioinformatics/bts199. PMID:22543367.

Kelly, L.J., Hollingsworth, P.M., Coppins, B.J., Ellis, C.J., Harrold, P., Tosh, J., and Yahr, R. 2011. DNA barcoding of lichenized fungi demonstrates high identification success in a floristic context. New Phytol.191: 288-300. doi:10.1111/j.14698137.2011.03677.x. PMID:21434928.

Kraichak, E., Divakar, P.K., Crespo, A., Leavitt, S.D., Nelsen, M.P., Lücking, R., and Lumbsch, H.T. 2015. A tale of two hyperdiversities: diversification dynamics of the two largest families of lichenized fungi. Sci. Rep. 5: 10028. doi:10.1038/srep10028. PMID:25944223.

Librado, P., and Rozas, J. 2009. DnaSP v5: a software for comprehensive analysis of DNA polymorphism data. Bioinformatics, 25: 1451-1452. doi:10.1093/bioinformatics/btp187. PMID:19346325.

Lindner, D.L., Carlsen, T., Nilsson, R.H., Davey, M., Schumacher, T., and Kauserud, H. 2013. Employing 454 amplicon pyrosequencing to reveal intragenomic divergence in the internal transcribed spacer rDNA region in fungi. Ecol. Evol. 3(6): 1751-1764. doi:10.1002/ece3.586. PMID:23789083. 
Lücking, R., Kalb, K., and Essene, A. 2012. The power of ITS: using megaphylogenies of barcoding genes to reveal inconsistencies in taxonomic identifications of Genbank submissions. In The 7th IAL Symposium: Lichens: from Genome to Ecosystems in a Changing World, January 2012, Bangkok, Thailand. Book of Abstracts, 3B-1-O2.

Lücking, R., Dal-Forno, M., Sikaroodi, M., Gillevet, P.M., Bungartz, F., Moncada, B., et al. 2014a. A single macrolichen constitutes hundreds of unrecognized species. Proc. Natl. Acad. Sci. U.S.A. 111: 11091-11096. doi:10.1073/pnas.1403517111. PMID: 24982168.

Lücking, R., Lawrey, J.D., Gillevet, P.M., Sikaroodi, M., Dal-Forno, M., and Berger, S.A. 2014b. Multiple ITS haplotypes in the genome of the lichenized basidiomycete Cora inversa (Hygrophoraceae): fact or artifact? J. Mol. Evol. 78: 148-162. doi:10.1007/s00239-013-9603-y. PMID:24343640.

Lumbsch, H.T., and Leavitt, S.D. 2011. Goodbye morphology? A paradigm shift in the delimitation of species in lichenized fungi. Fungal Divers. 50: 59-72. doi:10.1007/s13225-011-0123-z.

Madden, T. 2002. The BLAST sequence analysis tool. In The NCBI handbook. Edited by J. McEntyre and J. Ostell. National Center for Biotechnology Information, Bethesda, Md.

Margolin, B.S., Garrett-Engele, P.W., Stevens, J.N., Fritz, D.Y., Garrett-Engele, C., Metzenberg, R.L., and Selker, E.U. 1998. A methylated Neurospora 5S rRNA pseudogene contains a transposable element inactivated by repeat-induced point mutation. Genetics, 149: 1787-1797. PMID:9691037.

Margulies, M., Egholm, M., Altman, W.E., Attiya, S., Bader, J.S., Bemben, L.A., et al. 2005. Genome sequencing in microfabricated high-density picolitre reactors. Nature, 437: 376-380. PMID:16056220.

Mark, K., Saag, L., Leavitt, S.D., Will-Wolf, S., Nelsen, M.P., Tõrra, T., et al. 2016. Evaluation of traditionally circumscribed species in the lichen-forming genus Usnea, section Usnea (Parmeliaceae, Ascomycota) using a six-locus dataset. Org. Divers. Evol. [In press.] doi: doi:10.1007/s13127-0160273-7.

Martin, M. 2011. Cutadapt removes adapter sequences from high-throughput sequencing reads. EMBnet J. 17: 10-12. doi: 10.14806/ej.17.1.200.

Nash, T.H., III. 2008. Lichen biology. Cambridge University Press, Cambridge, UK.

NCBI Resource Coordinators. 2013. Database resources of the National Center for Biotechnology Information. Nucleic Acids Res. 41: D8-D20. doi:10.1093/nar/gks1189. PMID:23193264.

Nilsson, R.H., Tedersoo, L., Ryberg, M., Kristiansson, E., Hartmann, M., Unterseher, M., et al. 2015. A comprehensive, automatically updated fungal ITS sequence dataset for reference-based chimera control in environmental sequencing efforts. Microbes Environ. 30: 145-150. doi:10.1264/jsme2. ME14121. PMID:25786896.

Nimis, P.L., Scheidegger, C., and Wolseley, P.A. 2002. Monitoring with lichens - monitoring lichens. Springer, the Netherlands.

Orock, E.A., Leavitt, S.D., Fonge, B.A., St Clair, L.L., and Lumbsch, H.T. 2012. DNA-based identification of lichenforming fungi: can publicly available sequence databases aid in lichen diversity inventories of Mount Cameroon (West Africa)? Lichenologist, 44: 833-839. doi:10.1017/S0024282912000424.

Porter, T.M., and Golding, G.B. 2011. Are similarity- or phylogeny-based methods more appropriate for classifying internal transcribed spacer (ITS) metagenomic amplicons? New Phytol. 192: 775-782. doi:10.1111/j.1469-8137.2011. 03838.x. PMID:21806618.
Ratnasingham, S., and Hebert, P.D. 2007. BOLD: The Barcode of Life Data System. Mol. Ecol. Notes, 7: 355-364. Available at: www.boldsystems.org accessed 24 November 2015. PMID: 18784790.

Rooney, A.P., and Ward, T.J. 2005. Evolution of a large ribosomal RNA multigene family in filamentous fungi: birth and death of a concerted evolution paradigm. Proc. Natl. Acad. Sci. U.S.A. 102: 5084-5089. doi:10.1073/pnas.0409689102. PMID: 15784739.

Schmieder, R., and Edwards, R. 2011. Quality control and preprocessing of metagenomic datasets. Bioinformatics, 27: 863-864. doi:10.1093/bioinformatics/btr026. PMID:21278185.

Schoch, C.L., Seifert, K.A., Huhndorf, S., Robert, V., Spouge, J.L., Levesque, C.A., et al. 2012. Nuclear ribosomal internal transcribed spacer (ITS) region as a universal DNA barcode marker for Fungi. Proc. Natl. Acad. Sci. U.S.A. 109: 6241-6246. doi:10.1073/pnas.1117018109. PMID:22454494.

Seifert, K.A. 2009. Progress towards DNA barcoding of fungi. Mol. Ecol. Resour. 9: 83-89. PMID:21564968.

Sharifian, H. 2010. Errors induced during PCR amplification. M.Sc. thesis, Academic Department, Swiss Federal Institute of Technology, Zurich, Switzerland.

Shin, S., Lee, T.K., Han, J.M., and Park, J. 2014. Regional effects on chimera formation in 454 pyrosequenced amplicons from a mock community. J. Microbiol. 52: 566-573. doi:10.1007| s12275-014-3485-6. PMID:24879347.

Simon, U.K., and Weiß, M. 2008. Intragenomic variation of fungal ribosomal genes is higher than previously thought. Mol. Biol. Evol. 25: 2251-2254. doi:10.1093/molbev/msn188. PMID: 18728073.

Stamatakis, A. 2006. RAxML-VI-HPC: maximum likelihoodbased phylogenetic analyses with thousands of taxa and mixed models. Bioinformatics, 22: 2688-2690. doi:10.1093/ bioinformatics/btl446. PMID:16928733.

Stamatakis, A., Hoover, P., and Rougemont, J. 2008. A rapid bootstrap algorithm for the RAxML Web servers. Syst. Biol. 57: 758-771. doi:10.1080/10635150802429642. PMID:18853362.

Tamura, K., Peterson, D., Peterson, N., Stecher, G., Nei, M., and Kumar, S. 2011. MEGA5: molecular evolutionary genetics analysis using maximum likelihood, evolutionary distance, and maximum parsimony methods. Mol. Biol. Evol. 28: 27312739. doi:10.1093/molbev/msr121. PMID:21546353.

Truong, C., Divakar, P.K., Yahr, R., Crespo, A., and Clerc, P. 2013. Testing the use of ITS rDNA and protein-coding genes in the generic and species delimitation of the lichen genus Usnea (Parmeliaceae, Ascomycota). Mol. Phylogenet. Evol. 68: 357372. doi:10.1016/j.ympev.2013.04.005. PMID:23603312.

White, F., and James, P.W. 1985. A new guide to microchemical techniques for the identification of lichen substances. Br. Lichen Soc. Bull. 57: 1-41.

White, T.J., Bruns, T., Lee, S., and Taylor, J.W. 1990. Amplification and direct sequencing of fungal ribosomal RNA genes for phylogenetics. In PCR Protocols: A Guide to Methods and Applications. Edited by M.A. Innis, D.H. Gelfand, J.J. Sninsky, and T.J. White. Academic Press, New York. pp. 315-322.

Wörheide, G., Nichols, S.A., and Goldberg, J. 2004. Intragenomic variation of the rDNA internal transcribed spacers in sponges (Phylum Porifera): implications for phylogenetic studies. Mol. Phylogenet. Evol. 33: 816-830. doi:10.1016/j. ympev.2004.07.005. PMID:15522806.

Xu, J., Zhang, Q., Xu, X., Wang, Z., and Qi, J. 2009. Intragenomic variability and pseudogenes of ribosomal DNA in stone flounder Kareius bicoloratus. Mol. Phylogenet. Evol. 52: 157166. doi:10.1016/j.ympev.2009.03.031. PMID:19348952. 